\title{
Formation, Characterization, and Reactivity of Nonheme Iron(IV)-Oxo Complex Derived from the Chiral Pentadentate Ligand asN4Py
}

Dóra Lakk-Bogáth, ${ }^{\mathrm{a}}$ Róbert Csonka, ${ }^{\mathrm{a}}$ Gábor Speier, ${ }^{\mathrm{a}}$ Marius Réglier, ${ }^{\mathrm{b}}$ A. Jalila Simaan, ${ }^{*, \mathrm{~b}}$ JeanValère Naubron, ${ }^{\ddagger}$ Michel Giorgi, ${ }^{\text {c }}$ Károly Lázár, ${ }^{\text {d József Kaizer }}{ }^{*}$ a

${ }^{\dagger}$ Department of Chemistry, University of Pannonia, 8201 Veszprém, Hungary

${ }^{\S}$ Aix Marseille Université, CNRS, Centrale Marseille, iSm2 UMR 7313, 13397 Marseille, France

${ }^{\ddagger}$ Aix Marseille Université, CNRS, Centrale Marseille, Spectropole FR1739, 13397 Marseille, France

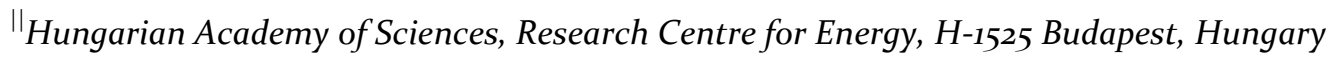

*Corresponding author. Tel.: +36 8862 4720; Fax: + 3688624469 .

E-mail address: kaizer@almos.vein.hu. 


\section{List of Contents}

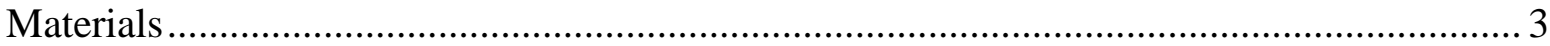

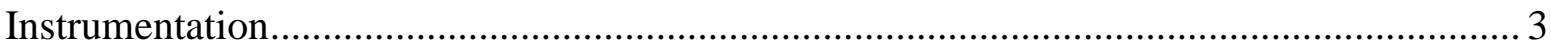

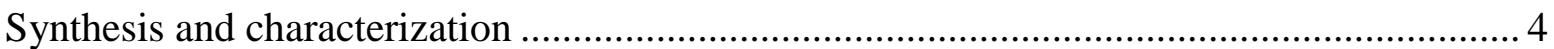

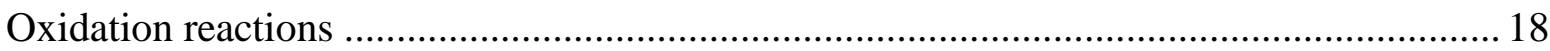

Description of the Fe(IV) intermediate formation with TBHP .................................. 18

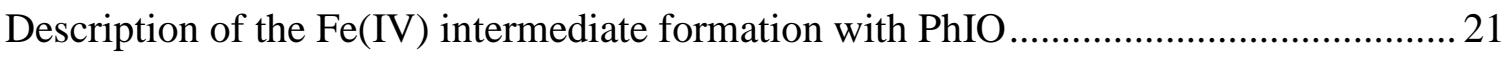

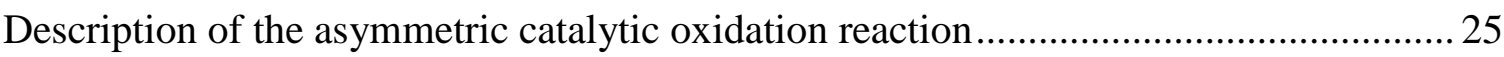

Description of the asymmetric stoichiometric oxidation reaction .................................... 26

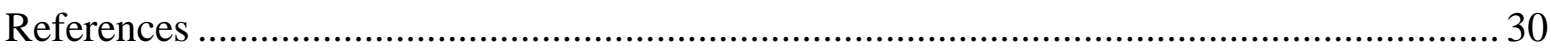




\section{Materials}

All syntheses were done under an argon atmosphere unless stated otherwise. Solvents used for the synthesis and reactions were purified by standard methods and stored under argon. The starting materials for the ligand are commercially available and they were purchased from Sigma-Aldrich.

\section{Instrumentation}

The crystal evaluation and intensity data collection for asN4Py and $\mathbf{1}\left(\mathrm{ClO}_{4}\right)_{2}$ was performed on a Bruker-Nonius Kappa CCD single-crystal diffractometer using Mo K $\alpha$ radiation $(\lambda=$ $0.71073 \AA$ ) at 293 K. Crystallographic data and selected bond lengths and angles are listed in Table S1 and Table S2, whereas details of the structure determination are given in Figure S1 and Figure S2. Comparison with similar N4Py-based complexes has been made and data is shown in Table S3. SHELX-2013 [1] was used for structure solution and full matrix least squares refinement on $F^{2}$.

The UV-visible spectra were recorded on an Agilent 8453 diode-array spectrophotometer using quartz cells.

IR spectra were recorded using a Thermo Nicolet Avatar 330 FT-IR instrument (Thermo Nicolet Corporation, Madison, WI, USA). Samples were prepared in the form of KBr pellets.

GC analyses were performed on an Agilent 6850 gas chromatograph equipped with a flame ionization detector and a $30 \mathrm{~m}$ SUPELCO BETA DEX 225 column, or a $30 \mathrm{~m}$ SUPELCO GAMMA DEX 120 column.

ESI- MS samples were analyzed using triple quadruple Micromass Quattro spectrometer (Waters, Milford, MA, USA), that was operated in positive electrospray ionization mode.

NMR spectrum was recorded on a Bruker Avance 400 spectrometer (Bruker Biospin AG, Fällanden, Switzerland).

Microanalyses (elemental analysis) were done by the Microanalytical Service of the University of Pannonia.

The enantiomeric separation of the ligand has been carried out on a HPLC Lux-Cellulose 2 column with a heptane/ethanol (50/50) mixture. The flow-rate was set to $1 \mathrm{~mL} / \mathrm{min}$.

Circular dichroism spectra were measured using a JASCO J-815 spectrometer equipped with Peltier cell holder PTC-423 to maintain the temperature at $20.0 \pm 0.2{ }^{\circ} \mathrm{C}$. Measurements were 
performed from 900 to $200 \mathrm{~nm}$ using $0.2 \mathrm{~nm}$ step size. The ligands or the complexes were placed at $1 \mathrm{mM}$ concentrations in acetonitrile.

Mössbauer spectra were recorded in a versatile in situ measuring cell which provides means to perform measurements at liquid nitrogen temperature as well [2]. $77 \mathrm{~K}$ spectra were collected with a KFKI spectrometer, equipped with $1 \mathrm{GBq}{ }^{57} \mathrm{Co} / \mathrm{Rh}$ source, operating in constant acceleration mode. Isomer shift values are related to metallic alpha-iron. Spectra were decomposed to Lorentzian shape lines, no parameters were constrained in the fits. The estimated accuracies of positional data is ca. $\pm 0.03 \mathrm{~mm} / \mathrm{s}$, and for the relative intensity data ca. $\pm 1 \%$.

Solid $\mathbf{1}\left(\mathrm{CF}_{3} \mathrm{SO}_{3}\right)_{2}$ sample was measured conventionally in powder form. Complex 2 was prepared by direct oxidation with iodosylbenzene in acetonitrile media. $\left(150 \mathrm{mg} \mathbf{1}\left(\mathrm{CF}_{3} \mathrm{SO}_{3}\right)_{2}\right.$ was mixed with $110 \mathrm{mg}$ iodosylbenzene in $1.5 \mathrm{ml}$ acetonitrile. The mixture was stirred for 2 h. After a short sedimentation $1 \mathrm{ml}$ of the upper clear deep green solution was placed into a sample holder and frozen immediately by immersion into liquid nitrogen.)

\section{Synthesis and characterization}

Preparation of asN4Py. Similarly to N4Py [3] the synthesis of the title ligand involves the alkylation of an amine (Scheme S1). The amine applied during ligand preparation is synthesized by literature method [4] and it was used without any further purification. $2.80 \mathrm{~g}$ (14.07 mmol) amine was mixed with 2.2 eq. (5.07 g, $30.95 \mathrm{mmol}$ ) 2-(chloromethyl)pyridine hydrochloride and 10 eq. $\mathrm{K}_{2} \mathrm{CO}_{3}(19.44 \mathrm{~g}, 140.7 \mathrm{mmol})$ in $200 \mathrm{ml} \mathrm{MeCN}$ and $10 \mathrm{ml}$ water. The mixture was refluxed for 24 hours then (after cooling down) filtered from excess carbonate. The clear red solution was evaporated partially under reduced pressure. $15 \mathrm{ml}$ water was added and the crude product was extracted with dichloromethane. The organic layer was dried with $\mathrm{NaSO}_{4}$ then the solvent was evaporated. The crude dark red solid material was washed with $10 \mathrm{ml}$ cold acetone to obtain nearly white powder. Yield: $2.27 \mathrm{~g}$ $(42 \%)$.

The chiral resolution of the ligand has been carried out by HPLC in a heptane/ethanol (50/50) mixture. The retention times of the enantiomers are $7.62 \mathrm{~min}$ and $13.79 \mathrm{~min}$ (Figure S1). The sample was dissolved in the solvent mixture, injected on the chiral column, and detected with an UV detector at $254 \mathrm{~nm}$ and identified by polarimeter. Optical rotations were measured on a 241 Perkin-Elmer polarimeter with a sodium lamp (589 nm), a mercury lamp (578 and 546 $\mathrm{nm})$ and a double-jacketed $10 \mathrm{~cm}$ cell at $25^{\circ} \mathrm{C}$. 


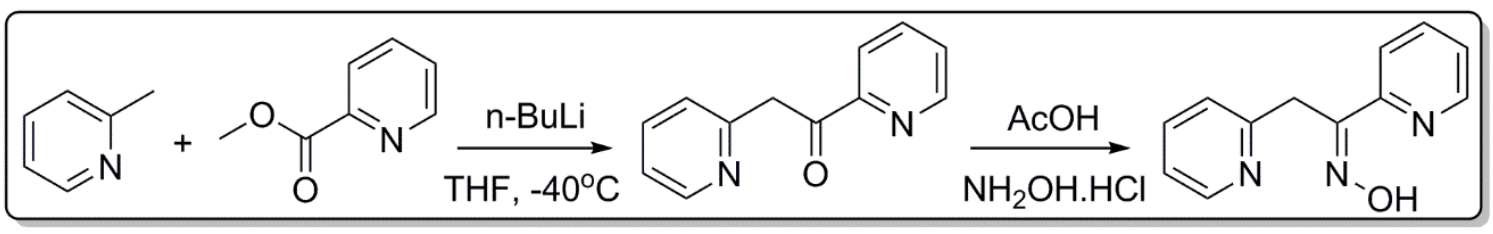

One pot synthesis

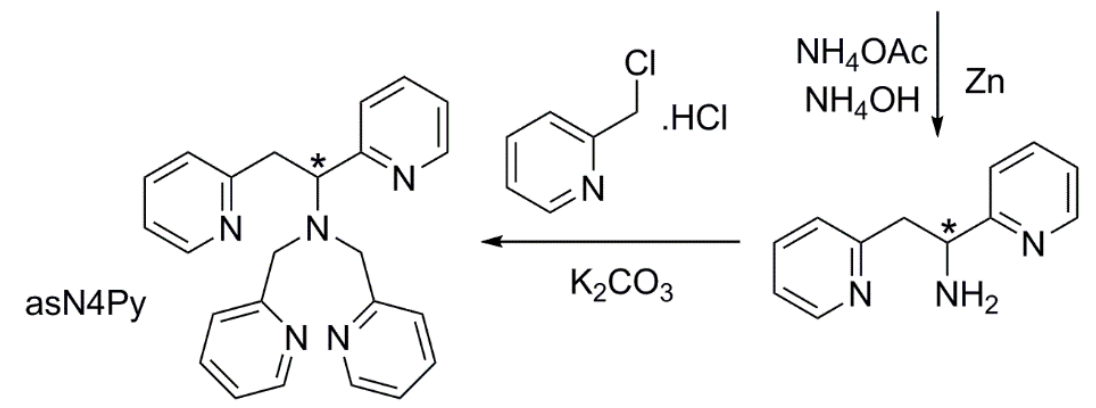

Scheme S1. Synthesis of asymmetric N4Py (asN4Py).

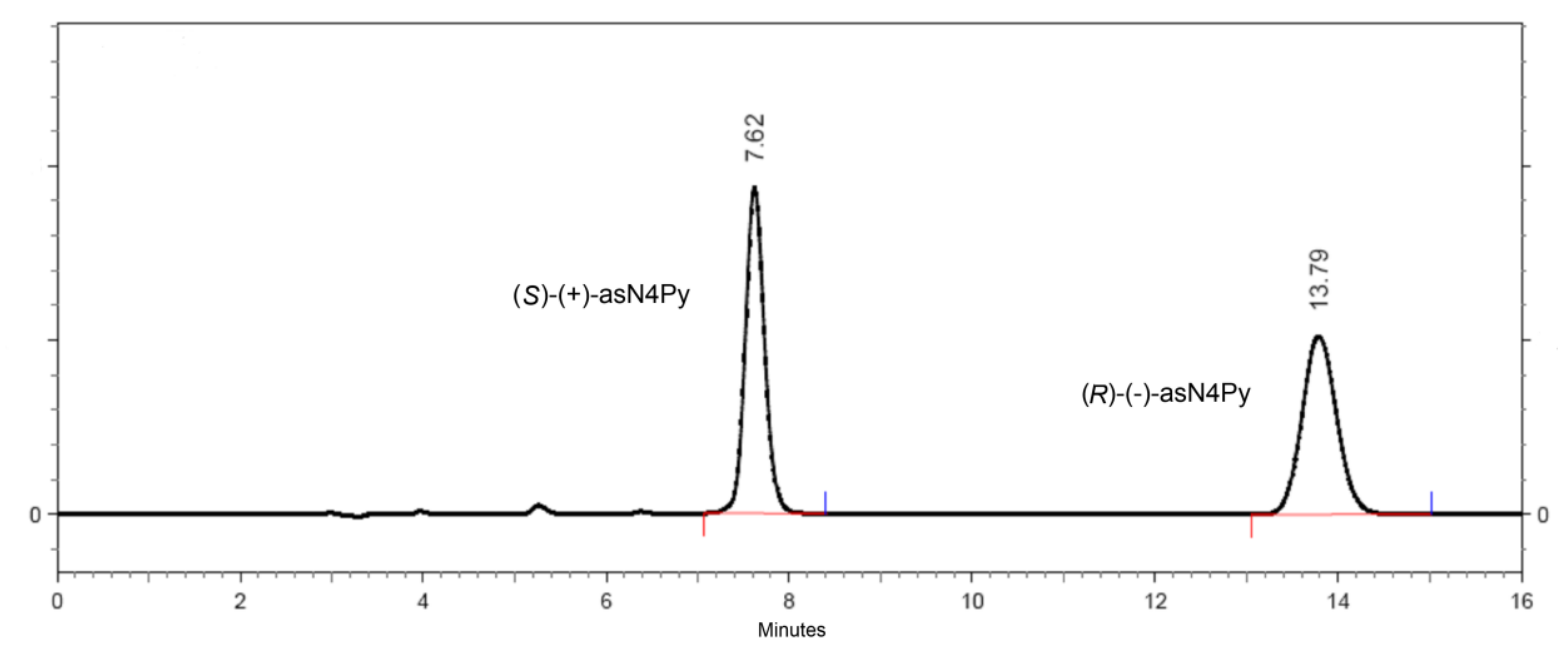

Figure S1. HPLC separation of the asN4Py enantiomers. First elute rotates polarized light clockwise $(+)$ in polarimeter and it is identified as $(S)$ enantiomer by VCD

Table S1. Specific rotations for asN4Py.

\begin{tabular}{c|c|c}
\hline$\lambda(\mathrm{nm})$ & $\begin{array}{c}\text { for the first eluted enantiomer on } \\
\text { Lux-Cellulose-2 }(-, \mathrm{CD} 254 \mathrm{~nm}) \\
{[\alpha]_{\lambda}{ }^{25}\left(\mathrm{CHCl}_{3}, \mathrm{c}=0.06\right)}\end{array}$ & $\begin{array}{c}\text { for the second eluted enantiomer } \\
\text { on Lux-Cellulose-2 }(+, \mathrm{CD} 254 \mathrm{~nm}) \\
{[\alpha]_{\lambda}^{25}\left(\mathrm{CHCl}_{3}, \mathrm{c}=0.06\right)}\end{array}$ \\
\hline 589 & +80 & -80 \\
578 & +82 & -82 \\
546 & +93 & -94 \\
\hline
\end{tabular}

$N, N$-bis(2-pyridylmethyl)-1,2-di(2-pyridyl)ethylamine (asN4Py): 
${ }^{1} \mathrm{H}-\mathrm{NMR}$ (400 MHz, DMSO): 8.59-8.57 (m, $\left.1 \mathrm{H}\right), 8.42-8.40(\mathrm{~m}, 2 \mathrm{H}), 8.37-8.35(\mathrm{~m}, 1 \mathrm{H})$, $7.74(\mathrm{dt}, J=8 \mathrm{~Hz}, 2 \mathrm{~Hz}, 1 \mathrm{H}), 7.61-7.54$ (m, $3 \mathrm{H}), 7.33-7.30$ (m, $1 \mathrm{H}), 7.27-7.10(\mathrm{~m}, 7 \mathrm{H})$, $4.46(\mathrm{t}, J=7 \mathrm{~Hz}, 1 \mathrm{H}), 4.03(\mathrm{~d}, J=15 \mathrm{~Hz}, 2 \mathrm{H}), 3.63(\mathrm{~d}, J=15 \mathrm{~Hz}, 2 \mathrm{H}), 3.53(\mathrm{dd}, J=14 \mathrm{~Hz}$, $7 \mathrm{~Hz}, 1 \mathrm{H}), 3.45$ (dd, $J=14 \mathrm{~Hz}, 7 \mathrm{~Hz}, 1 \mathrm{H}) .{ }^{13} \mathrm{C}-\mathrm{NMR}$ (100 MHz, DMSO) $\delta$ (ppm): 38.19, 56.06, 63.82, 121.0, 121.8, 122.1, 122.3, 124.0, 124.0, 135.8, 136.0, 136.2, 148.5, 148.6, 148.7, 158.1, 159.5, 159.8. IR (KBr, cm $\left.{ }^{-1}\right): 3445$ w, 3051 w, 3006 w, 2823 w, 1588 s, 1567 m, 1472 s, 1431 s, 1368 w, 1354 w, 1285 w, 1244 w, 1138 w, 1120 w, 1049 m, 995 m, 959 w, 893 w, 835 w, 772 m, 761 s, 668 w, 630 w, 566 w, 519 w, 496 w. UV-vis (MeCN) $\lambda \max (\log$ $\varepsilon, \mathrm{dm}^{3} \mathrm{~mol}^{-1} \mathrm{~cm}^{-1}$ ): 282 (3.22). Anal. Calcd. for $\mathrm{C}_{24} \mathrm{H}_{23} \mathrm{~N}_{5}$ (381.47): C, 75.56; H, 6.08; N, 18.36. Found C, 75.47; H, 6.10; N, 18.32 . 


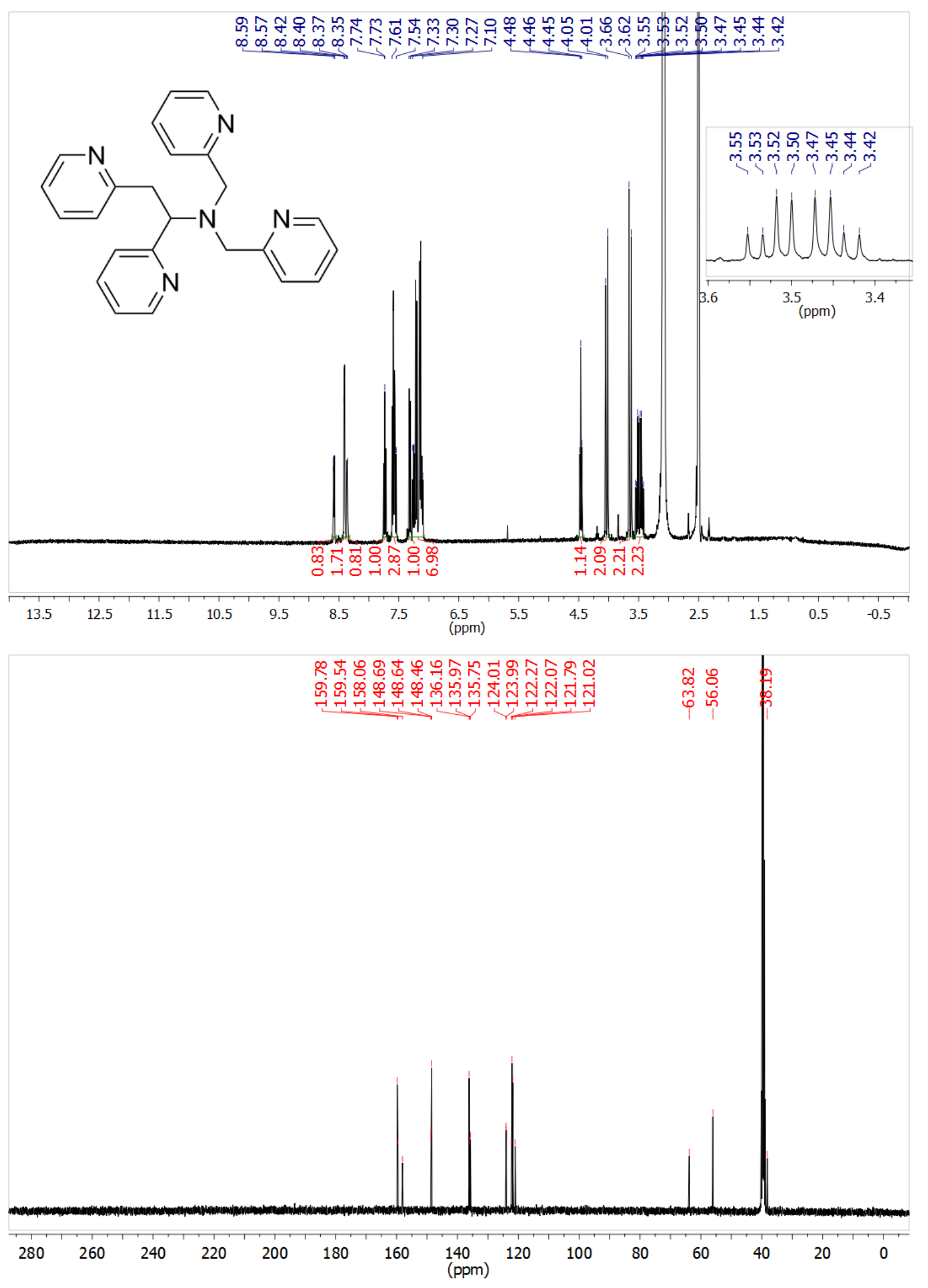

Figure S2. ${ }^{1} \mathrm{H}-\mathrm{NMR}$ (top) and ${ }^{13} \mathrm{C}-\mathrm{NMR}$ (bottom) spectra of asN4Py in DMSO. 


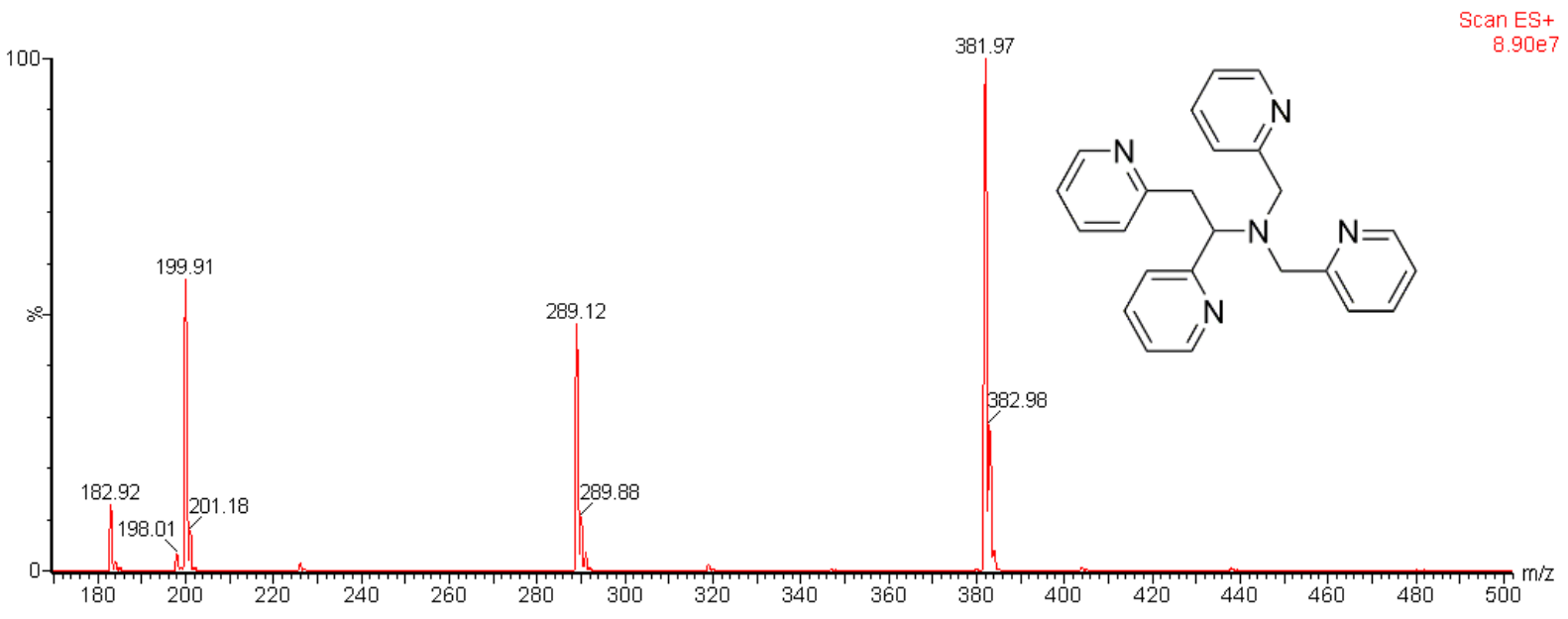

Figure S3. Electrospray ionization mass spectrum of asN4Py. (Calculated $\mathrm{m} / \mathrm{z}$ of 381.2)

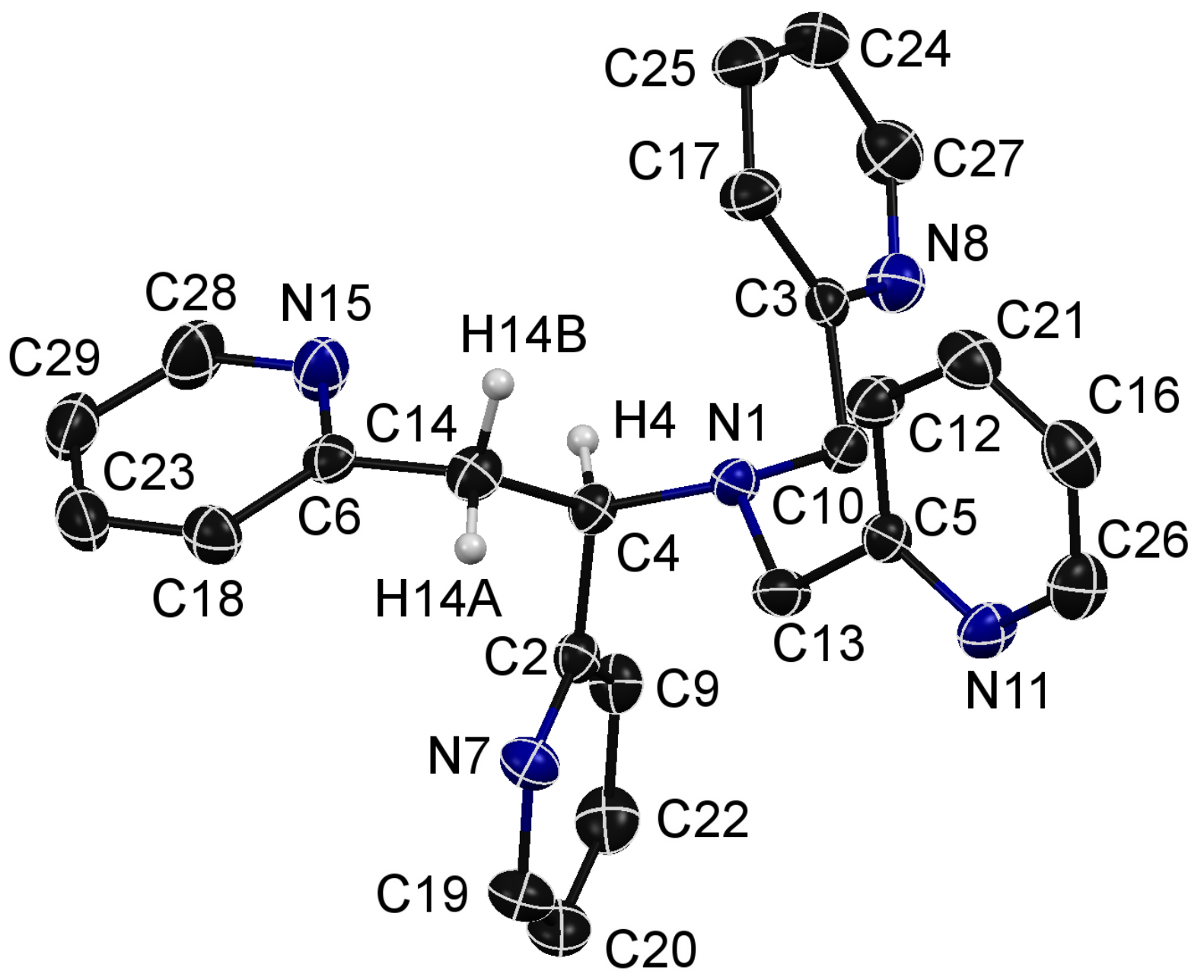

Figure S4. X-ray structure of the ligand asN4Py. Thermal ellipsoids are plotted at 50\% probability level. Hydrogen atoms omitted for clarity. 


\section{VCD and ECD Measurements}

Infrared (IR) and vibrational circular dichroism (VCD) spectra were recorded on a Bruker PMA 50 accessory coupled to a Vertex70 Fourier transform infrared spectrometer. A photoelastic modulator (Hinds PEM 90) set at 1/4 retardation was used to modulate the handedness of the circular polarized light at $50 \mathrm{kHz}$. Demodulation was performed by a lockin amplifier (SR830 DSP). An optical low-pass filter $\left(<1800 \mathrm{~cm}^{-1}\right)$ before the photoelastic modulator was used to enhance the signal/noise ratio. A transmission cell equipped with $\mathrm{BaF}_{2}$ windows and of $200 \mu \mathrm{m}$ of optical pathlength was used. Solutions with a concentration of 0.1 mol L $\mathrm{L}^{-1}$ were prepared by dissolving the solid samples in $\mathrm{CD}_{2} \mathrm{Cl}_{2}$. The VCD spectra of the pure enantiomers (+)-as $\mathrm{N}_{4} \mathrm{PY}$ and (-)-as $\mathrm{N}_{4} \mathrm{PY}$ were measured at room temperature and the baseline of the spectra were corrected using the standard procedure of the half-substraction of the spectra of each enantiomer. For each individual spectrum, about 12000 scans were averaged at $4 \mathrm{~cm}^{-1}$ resolution (corresponding to 3 hours measurement time). For IR absorption spectra, the cell filled with $\mathrm{CD}_{2} \mathrm{Cl}_{2}$ served as a reference. The spectra are presented without smoothing and further data processing.

ECD spectra were measured on a JASCO J-815 spectrometer equipped with a JASCO Peltier cell holder PTC-423 to maintain the temperature at $20.0 \pm 0.2{ }^{\circ} \mathrm{C}$. A quartz cell of $1 \mathrm{~mm}$ of optical path length was used. Solutions with a concentration of $1.4 \times 10^{-3} \mathrm{~mol} \mathrm{~L}^{-1}$ were prepared in ethanol (HPLC grade). The CD spectrometer was purged with nitrogen during the recording of spectra. The UV absorption and ECD spectra were recorded using ethanol as a reference and are presented without smoothing and further data processing.

\section{Theoretical calculations}

Calculations were performed on the $(S)-\mathrm{asN}_{4} \mathrm{PY}$ enantiomer. The conformational study was done using a stochastic exploration of the potential energy surface (PES) using simulated annealing with RM1 semi-empirical level as implemented in Ampac10. ${ }^{1}$ A set of 97 geometries of conformations were generated using 4 simulated annealing, each done with a different geometry or parameterized with a different initial temperature. A geometry optimized using density functional theory (DFT) with CAM-B3LYP functional and DGTZVP basis set has been used as starting structure. Only the dihedral angles of this initial geometry were allowed to relax during the annealing, the bonds lengths and the valences angles were kept constant. Then, the first twenty conformations, with energy lower than $2.5 \mathrm{kcal} \mathrm{mol}^{-1}$ compared to the lower energy conformation, were kept. They have been fully optimized using CAM-B3LYP functional combined with 6-311G(d,p) basis set. Average solvent effects were 
introduced using the SMD solvation model. Based on Boltzmann statistic, we estimated population of the conformations. Only five conformations have been retained to build the average theoretical spectra. Their vibrational frequencies, IR absorption and VCD intensities were calculated with the same theoretical level as used for the optimizations. Computed harmonic frequencies are generally larger than those experimentally observed. They have been calibrated using a scaling factor of 0.96. IR absorption and VCD spectra were constructed from calculated dipole and rotational strengths assuming Lorentzian band shape with a half-width at half maximum of $10 \mathrm{~cm}^{-1}$. Based on CAM-B3LYP/DGTZVP optimized geometries, the ECD and UV spectra were calculated using time dependent density functional theory (TD-DFT) with CAM-B3LYP functional and $6-31++\mathrm{G}(\mathrm{d}, \mathrm{p})$ basis set. Calculations were performed for vertical 1A singlet excitation using 40 states. The Boltzmann populations of the 4 conformations retained to build the UV/ECD average spectra have been estimated using Gibbs energies calculated at CAM-B3LYP/DGTZVP level. For a comparison between theoretical results and the experimental values, the calculated UV and ECD spectra have been modeled with a Gaussian function, using a half-width of $0.3 \mathrm{eV}$. Several combinations of funtionnal and basis set were used to calculate VCD and ECD spectra in order to check the reliability of the calculations. All are similar and converge to the same absolute configuration: (+)-(S)-asN 4 PY. However, only SMD/CAM-B3LYP/6-311G(d,p) for VCD and CAM-B3LYP/6-31++G(d,p)//CAM-B3LYP/DGTZVP are given in figures 1 and 2 respectively. All calculations were performed using Gaussian 09 package. [5,6] 

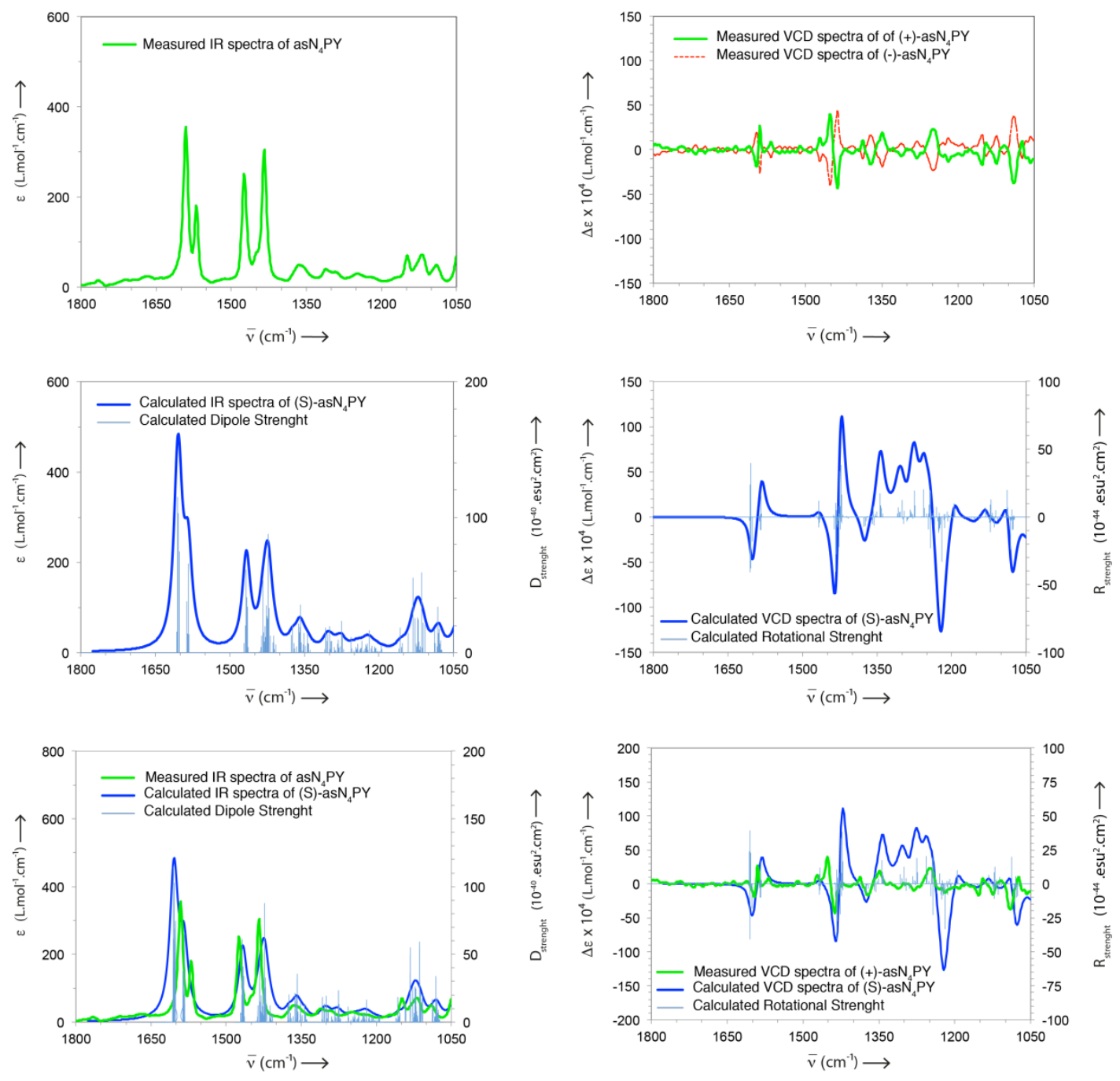

Figure S5 Experimental IR and VCD spectra for, (-) - asN $\mathrm{N}_{4} \mathrm{PY}$ (red line); (+) - asN $\mathrm{a}_{4} \mathrm{PY}$ (green lines) and calculated for (S)- $\mathrm{asN}_{4} \mathrm{PY}$ (blue lines). 

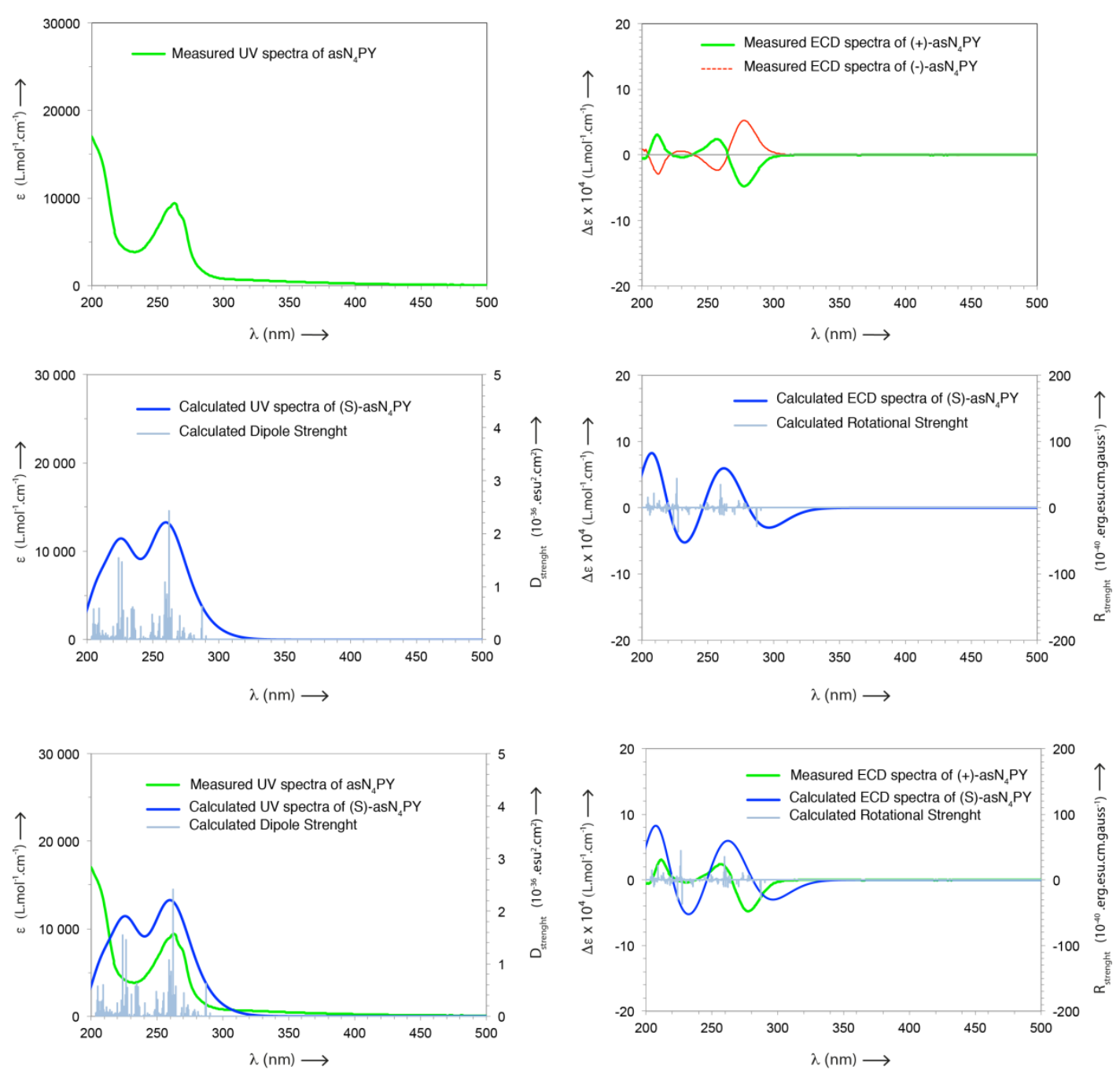

Figure S6 Experimental UV and ECD spectra for, (-) - $\operatorname{asN}_{4} \mathrm{PY}$ (red line); (+) - asN $\mathrm{a}_{4} \mathrm{PY}$ (green lines) and calculated for (S)- $\operatorname{asN}_{4} \mathrm{PY}$ (blue lines).

Preparation of $\left[\mathrm{Fe}^{\mathrm{II}}(\mathbf{a s N 4 P y}) \mathrm{MeCN}\right]\left(\mathrm{ClO}_{4}\right)_{2} \quad 0.300 \mathrm{~g}(0.786 \mathrm{mmol})$ ligand and $0.285 \mathrm{~g}$ $(0.786 \mathrm{mmol}) \mathrm{Fe}^{\mathrm{II}}\left(\mathrm{ClO}_{4}\right)_{2} \times 6 \mathrm{H}_{2} \mathrm{O}$ were dissolved in $2 \mathrm{ml} \mathrm{MeOH}-\mathrm{MeCN}$ (1:1) mixture under Ar. The mixture was stirred at RT for 1 hour. $0.5 \mathrm{ml}$ EtOAc was layered onto the surface of the solution and it was placed to the freezer $\left(-40^{\circ} \mathrm{C}\right)$. Cubic shaped red crystals formed during overnight. Yield: $0.471 \mathrm{~g}(89 \%)$.

A slightly modified version of the title complex has been synthesized for the Mössbauer measurements with $\mathrm{Fe}^{\mathrm{II}}\left(\mathrm{CF}_{3} \mathrm{SO}_{3}\right)_{2}$ instead of the perchlorate salt. The $\mathrm{Fe}^{\mathrm{IV}}=\mathrm{O}$ intermediates formed by $\mathrm{PhIO}$ show identical spectroscopic properties. 


\section{$\left[\mathrm{Fe}^{\mathrm{II}}(\operatorname{asN} 4 \mathrm{Py})(\mathrm{MeCN})\right]\left(\mathrm{ClO}_{4}\right)_{2}$ :}

FT-IR (KBr, cm ${ }^{-1}$ ): 3433 m, 1604 m, 1480 w, 1439 m, 1287 w, 1341 w, 1090 s, 912 w, 766 m, $625 \mathrm{~m}$. UV-Vis (MeCN) $\lambda \max \left(\log \varepsilon, \mathrm{dm}^{3} \mathrm{~mol}^{-1} \mathrm{~cm}^{-1}\right): 398$ (3.94), 409 (3.91), 514 (1.14). Anal. Calcd. for $\mathrm{C}_{26} \mathrm{H}_{26} \mathrm{Cl}_{2} \mathrm{FeN}_{6} \mathrm{O}_{8}$ (677.27): C, 46.11; H, 3.87; N, 12.41. Found C, 46.13; H, $3.87 ; \mathrm{N}, 12.37$.

\section{$\left[\mathrm{Fe}^{\mathrm{II}}(\operatorname{asN} 4 \mathrm{Py})(\mathrm{MeCN})\right]\left(\mathrm{CF}_{3} \mathrm{SO}_{3}\right)_{2}$ :}

Anal. Calcd. for $\mathrm{C}_{28} \mathrm{H}_{26} \mathrm{~F}_{6} \mathrm{FeN}_{6} \mathrm{O}_{6} \mathrm{~S}_{2}$ (776.51): C, 43.31; H, 3.38; N, 10.82. Found C, 43.33; H, 3.39; N, 10.80 .

Table S2. Summary of crystal data and intensity collection and structure refinement parameters for the asN4Py and its complex $\mathbf{1}\left(\mathrm{ClO}_{4}\right)_{2}$.

\begin{tabular}{l|l|l}
\hline Compound & asN4Py & $\mathbf{1}\left(\mathrm{ClO}_{4}\right)_{2}$ \\
\hline Chemical formula & $\mathrm{C}_{24} \mathrm{H}_{23} \mathrm{~N}_{5}$ & $\mathrm{C}_{32} \mathrm{H}_{35} \mathrm{Cl}_{2} \mathrm{FeN}_{9} \mathrm{O}_{8}$ \\
Formula weight & 381.47 & 800.44 \\
Crystal system & triclinic & monoclinic \\
Space group & $\mathrm{P}-1$ & $\mathrm{P} 2_{1} / \mathrm{C}$ \\
$a(\AA)$ & $8.6788(6)$ & $12.9962(6)$ \\
$b(\AA)$ & $8.8994(4)$ & $23.5193(11)$ \\
$c(\AA)$ & $13.9946(9)$ & $17.3109(8)$ \\
$\alpha\left(^{\circ}\right)$ & $102.349(5)$ & 90.0 \\
$\beta\left(^{\circ}\right)$ & $104.313(6)$ & $135.6985(41)$ \\
$\gamma\left({ }^{\circ}\right)$ & $95.215(5)$ & 90.0 \\
Volume $\left(\AA^{3}\right)$ & $1011.24(11)$ & $3695.61(3)$ \\
$Z$ & 2 & 4 \\
Calc. density $\left(\mathrm{g} \mathrm{cm}{ }^{-1}\right)$ & 1.253 & 1.439 \\
Temperature $(\mathrm{K})$ & 293 & $293(2)$ \\
Abs. coeff. $\left(\mathrm{mm}^{-1}\right)$ & 0.077 & 0.614 \\
$F(000)$ & 404.12 & 1656 \\
Obs. reflections & 4686 & 5859 \\
Goodness-of-fit & 1.088 & 1.046 \\
$R_{1}{ }^{a}$ & 0.0582 & 0.0816 \\
$w \mathrm{R}_{2}$ & 0.1281 & 0.2055 \\
\hline${ }^{\mathrm{a}} w=1\left\lceil\sigma^{2}\left(F_{\mathrm{o}}{ }^{2}\right)+(\alpha P)^{2}+b P\right]$ and $\left.P=\left(\max F_{o}{ }^{2}, 0\right)+2 F_{c}{ }^{2}\right) / 3$ \\
$R_{1}=\Sigma\left(\left|F_{\mathrm{o}}\right|-\left|F_{\mathrm{c}}\right|\right) / \Sigma\left(\left|F_{\mathrm{o}}\right|\right)$ and $w R_{2}=\left\{\Sigma\left[w\left(F \mathrm{o}^{2}-F \mathrm{c}^{2}\right)^{2}\right] / \Sigma\left[w\left(F_{\mathrm{o}}{ }^{2}\right)^{2}\right]\right\}^{1 / 2}$
\end{tabular}

Table S3. Selected bond distances $(\AA)$ and angles $\left(^{\circ}\right)$ for $\mathbf{1}\left(\mathrm{ClO}_{4}\right)_{2}$ complex

\begin{tabular}{cl|ll}
\hline \multicolumn{2}{c|}{ distances } & \multicolumn{2}{c}{ angles } \\
\hline $\mathrm{Fe}(1)-\mathrm{N}(6)$ & $1.944(4)$ & $\mathrm{N}(1)-\mathrm{Fe}(1)-\mathrm{N}(2)$ & $91.0(2)$ \\
$\mathrm{Fe}(1)-\mathrm{N}(2)(\mathrm{as})$ & $2.037(3)$ & $\mathrm{N}(2)-\mathrm{Fe}(1)-\mathrm{N}(6)$ & $91.3(2)$ \\
$\mathrm{Fe}(1)-\mathrm{N}(5)$ & $1.965(7)$ & $\mathrm{N}(2)-\mathrm{Fe}(1)-\mathrm{N}(5)$ & $89.0(2)$ \\
$\mathrm{Fe}(1)-\mathrm{N}(4)$ & $1.974(3)$ & $\mathrm{N}(5)-\mathrm{Fe}(1)-\mathrm{N}(4)$ & $88.8(2)$ \\
$\mathrm{Fe}(1)-\mathrm{N}(3)$ & $1.964(7)$ & $\mathrm{N}(4)-\mathrm{Fe}(1)-\mathrm{N}(3)$ & $90.0(2)$ \\
$\mathrm{Fe}(1)-\mathrm{N}(1)$ & $1.972(4)$ & $\mathrm{N}(1)-\mathrm{Fe}(1)-\mathrm{N}(5)$ & $84.7(2)$ \\
\hline
\end{tabular}


Table S4. Comparison of different $\mathrm{Fe}-\mathrm{N}$ bond distances $(\AA)$ between $\mathrm{Fe}(\mathrm{N} 4 \mathrm{Py})$ derivates $\left(\mathrm{N}_{\text {div }}=\right.$ diverse or nonregular pyridyl moiety $)$

\begin{tabular}{c|c|c|c|c|c}
\hline entry & $\begin{array}{c}\mathrm{Fe}-\mathrm{N}_{\text {py }} \\
\text { (av) }\end{array}$ & $\begin{array}{c}\mathrm{Fe}-\mathrm{N}_{\text {div }} \\
(\mathrm{av})\end{array}$ & $\mathrm{Fe}-\mathrm{N}_{\mathrm{MeCN}}$ & $\mathrm{Fe}-\mathrm{N}_{\text {amine }}$ & ref. \\
\hline$\left[\mathrm{Fe}^{\mathrm{II}}(\right.$ asN4Py $\left.)(\mathrm{MeCN})\right]\left(\mathrm{ClO}_{4}\right)_{2}$ & 1.968 & $2.037(3)$ & $1.944(4)$ & $1.972(4)$ & \\
{$\left[\mathrm{Fe}^{\mathrm{II}}(\mathrm{N} 3 \mathrm{PyBzIM})(\mathrm{MeCN})\right]\left(\mathrm{ClO}_{4}\right)_{2}$} & 1.953 & 1.977 & $1.909(6)$ & $1.980(6)$ & {$[7]$} \\
{$\left[\mathrm{Fe}^{\mathrm{II}}(\mathrm{N} 2 \mathrm{Py} 2 \mathrm{BzIM})(\mathrm{MeCN})\right]\left(\mathrm{ClO}_{4}\right)_{2}$} & 1.974 & 1.981 & $1.901(3)$ & $2.028(2)$ & {$[7]$} \\
{$\left[\mathrm{Fe}^{\mathrm{II}}(\mathrm{N} 4 \mathrm{Py})(\mathrm{MeCN})\right]\left(\mathrm{ClO}_{4}\right)_{2}$} & 1.972 & - & $1.915(3)$ & $1.961(3)$ & {$[8]$} \\
\hline
\end{tabular}

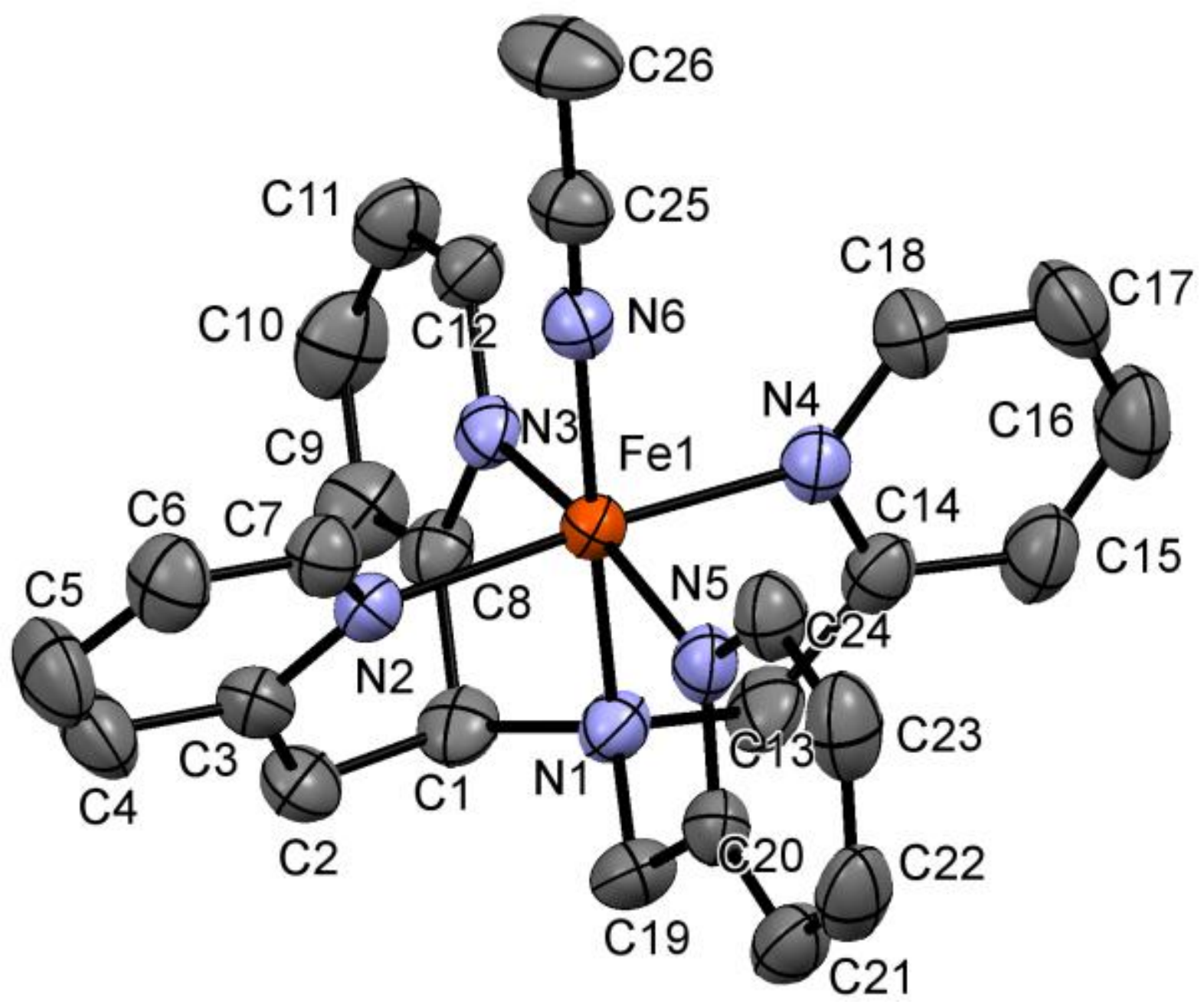

Figure S7. X-ray structure of $\mathbf{1}\left(\mathrm{ClO}_{4}\right)_{2}$. Thermal ellipsoids are plotted at $50 \%$ probability level. Outer sphere solvent molecules, hydrogen atoms and perchlorate anions were omitted for clarity. 


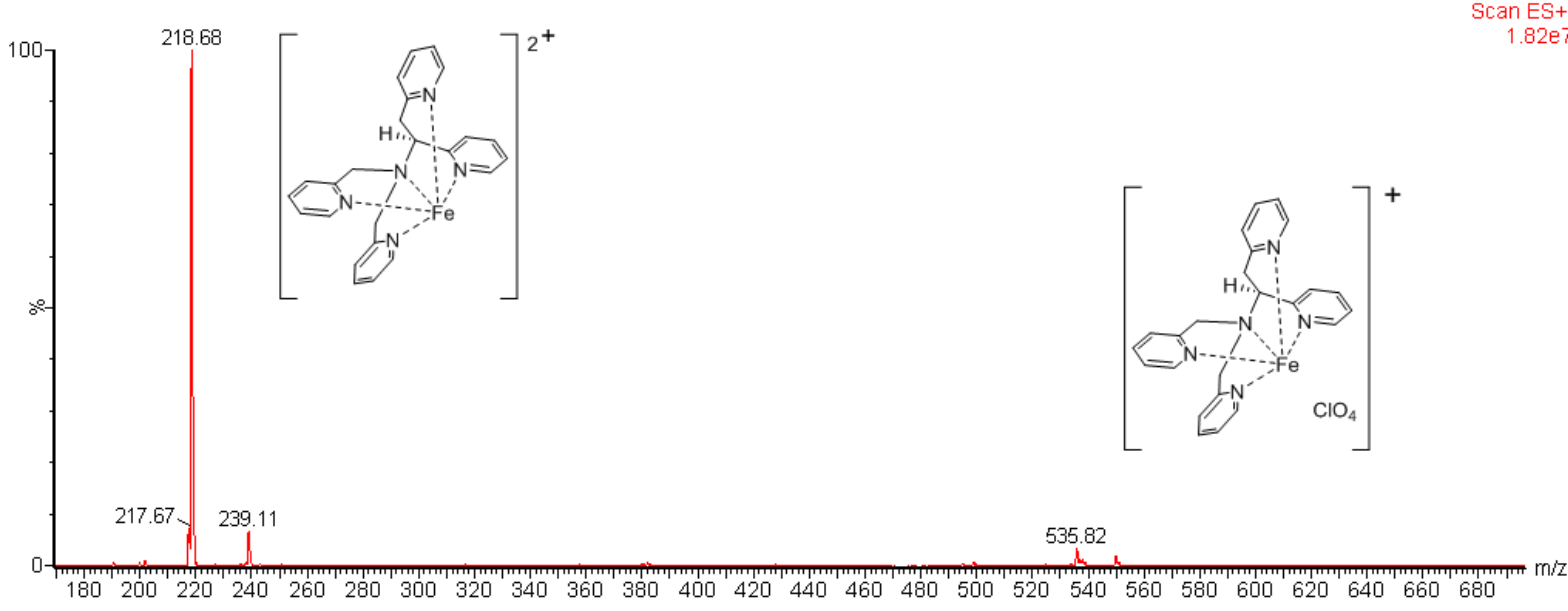

Figure S8. Electrospray ionization mass spectrum of $\mathbf{1}\left(\mathrm{ClO}_{4}\right)_{2}$. The peaks at $\mathrm{m} / \mathrm{z}$ values 218.68, 239.11 and 535.82 correspond to the formulae $\left[\mathrm{Fe}^{\mathrm{II}}(\operatorname{asN} 4 \mathrm{Py})\right]^{2+}(\mathrm{z}=2)$, $\left[\mathrm{Fe}^{\mathrm{II}}(\operatorname{asN} 4 \mathrm{Py})\left(\mathrm{CH}_{3} \mathrm{CN}\right)\right]^{2+}(\mathrm{z}=2)$ and $\left[\mathrm{Fe}^{\mathrm{II}}(\operatorname{asN} 4 \mathrm{Py})\left(\mathrm{ClO}_{4}\right)\right]^{+}(\mathrm{z}=1)$, respectively.

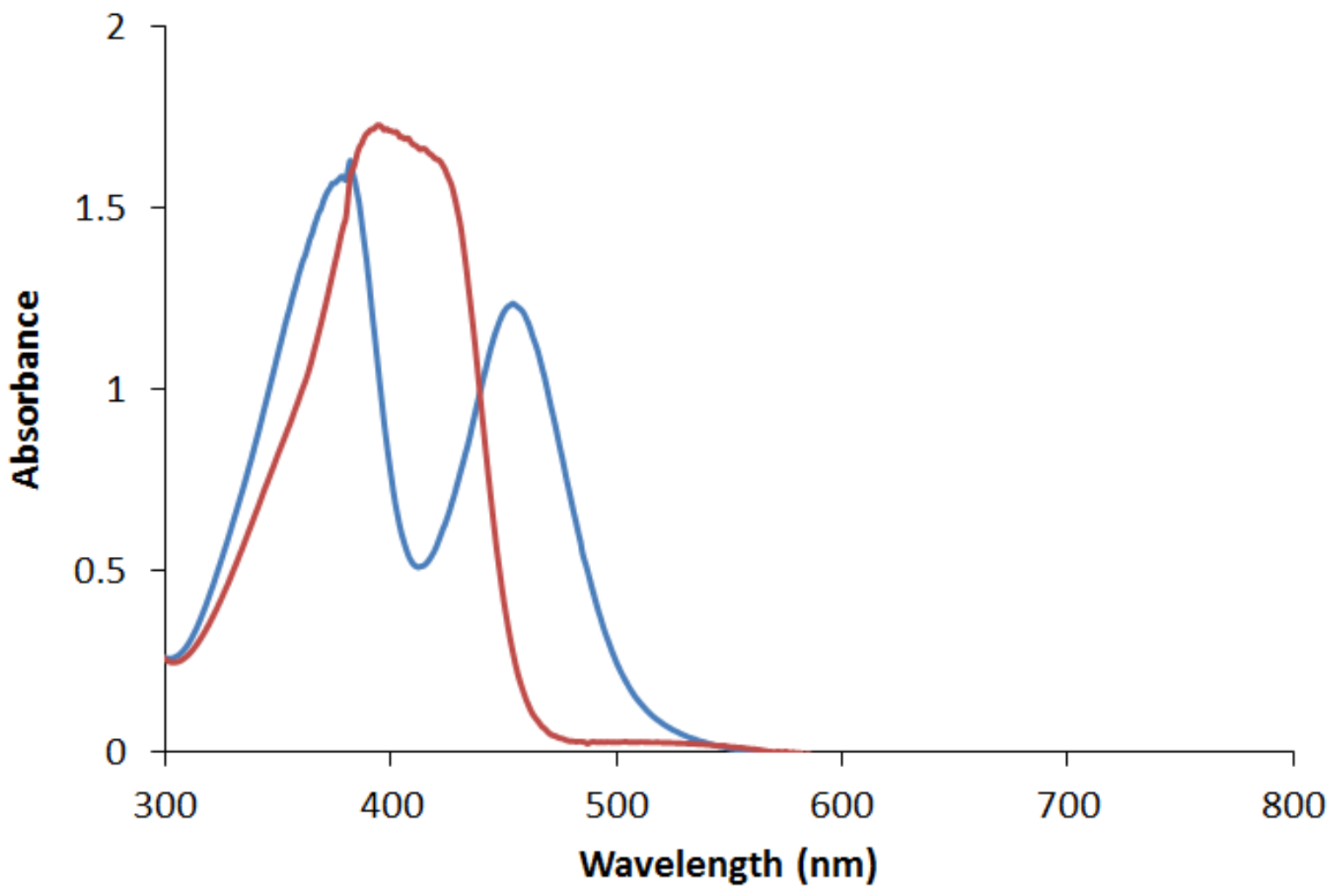

Figure S9. UV-Vis spectra of complexes $\left[\mathrm{Fe}^{\mathrm{II}}(\mathrm{N} 4 \mathrm{Py})(\mathrm{MeCN})\right]\left(\mathrm{ClO}_{4}\right)_{2}$ (blue) and $\left[\mathrm{Fe}^{\mathrm{II}}\right.$ (asN4Py)(MeCN)]($\left(\mathrm{ClO}_{4}\right)_{2}$ (red) $(0.20 \mathrm{mM})$ in acetonitrile recorded at room temperature $(298 \mathrm{~K})$. 


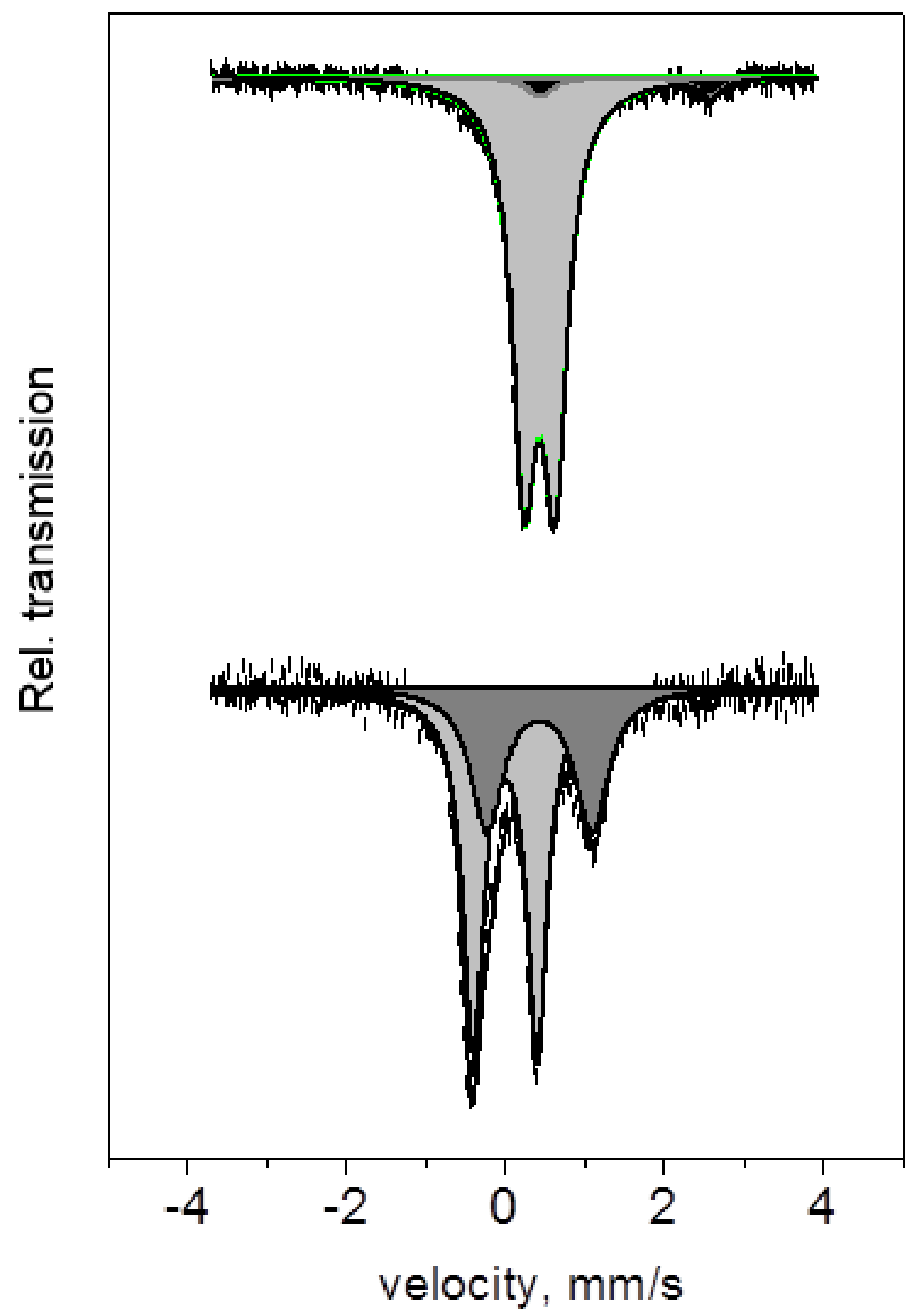

Figure S10. (Bottom) ${ }^{57} \mathrm{Fe}$ Mössbauer spectrum of $\mathbf{2}\left(\mathrm{CF}_{3} \mathrm{SO}_{3}\right)_{2}$ (light gray) in acetonitrile solution $(148 \mathrm{mM})$ measured at $77 \mathrm{~K}(63 \%)$. The minor black subspectrum corresponds to ca. $37 \%$ of an $\mathrm{Fe}(\mathrm{III})$ impurity, tentatively assigned to the oxo-bridged dinuclear complex $\left[\left\{\mathrm{Fe}^{\mathrm{III}}(\text { asN4Py })\right\}_{2}(\mu-\mathrm{O})\right]^{4+}$ (see text). (Top) Zero-field Mössbauer spectrum of the powder of 1. $\left(\mathrm{CF}_{3} \mathrm{SO}_{3}\right)_{2}$ (light gray) at $77 \mathrm{~K}$. 


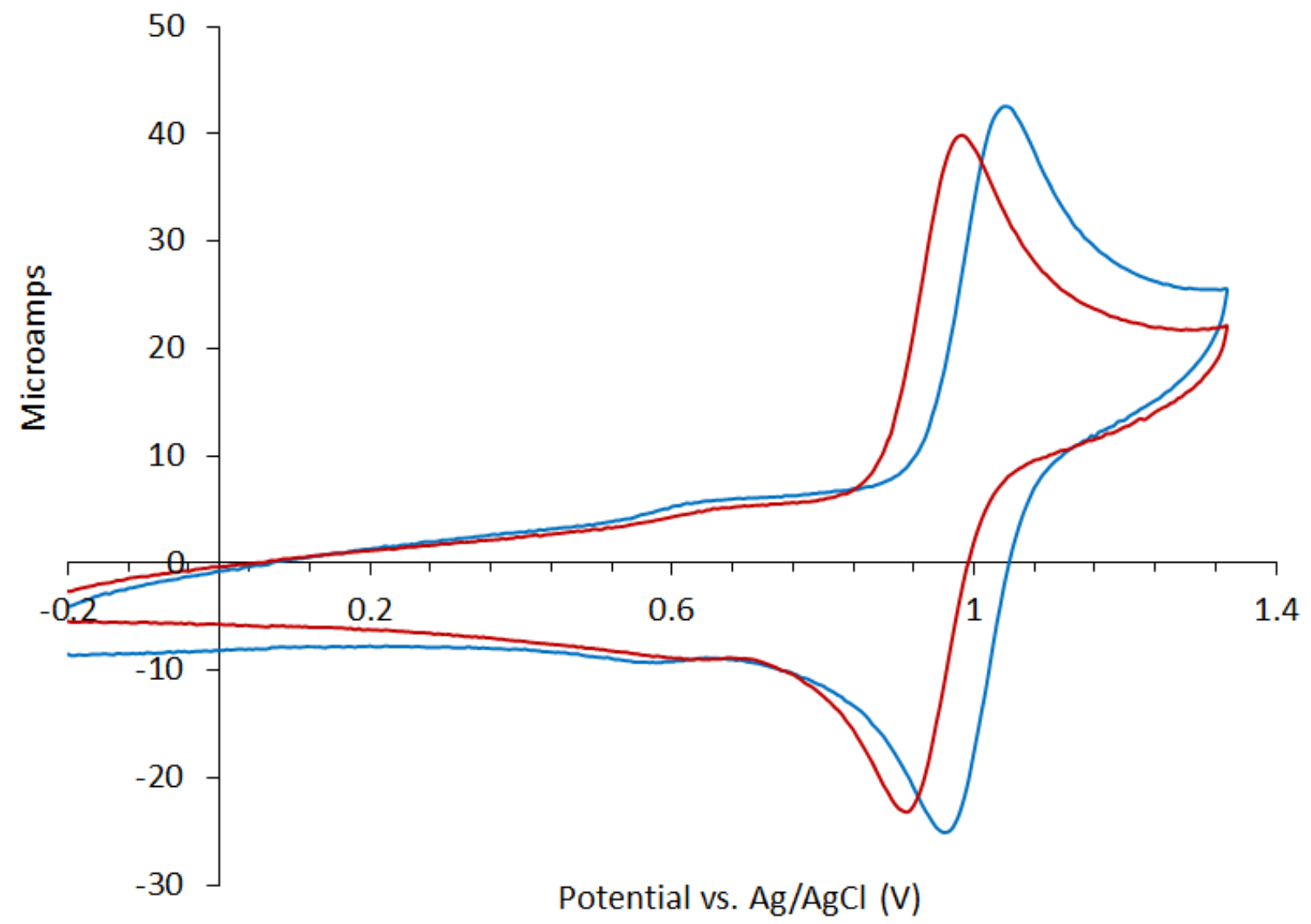

Figure S11. Cyclic voltammograms of $1 \mathrm{mM}$ Fe(N4Py) (blue) and Fe(asN4Py) (red) in $\mathrm{CH}_{3} \mathrm{CN}$ with $0.1 \mathrm{M}\left(\mathrm{Bu}_{4} \mathrm{~N}\right) \mathrm{ClO}_{4}$; scan rate $100 \mathrm{mVs}^{-1}$; working electrode: glassy carbon electrode (GCE), auxiliary electrode: Pt wire, reference electrode: $\mathrm{Ag} / \mathrm{AgCl}$.

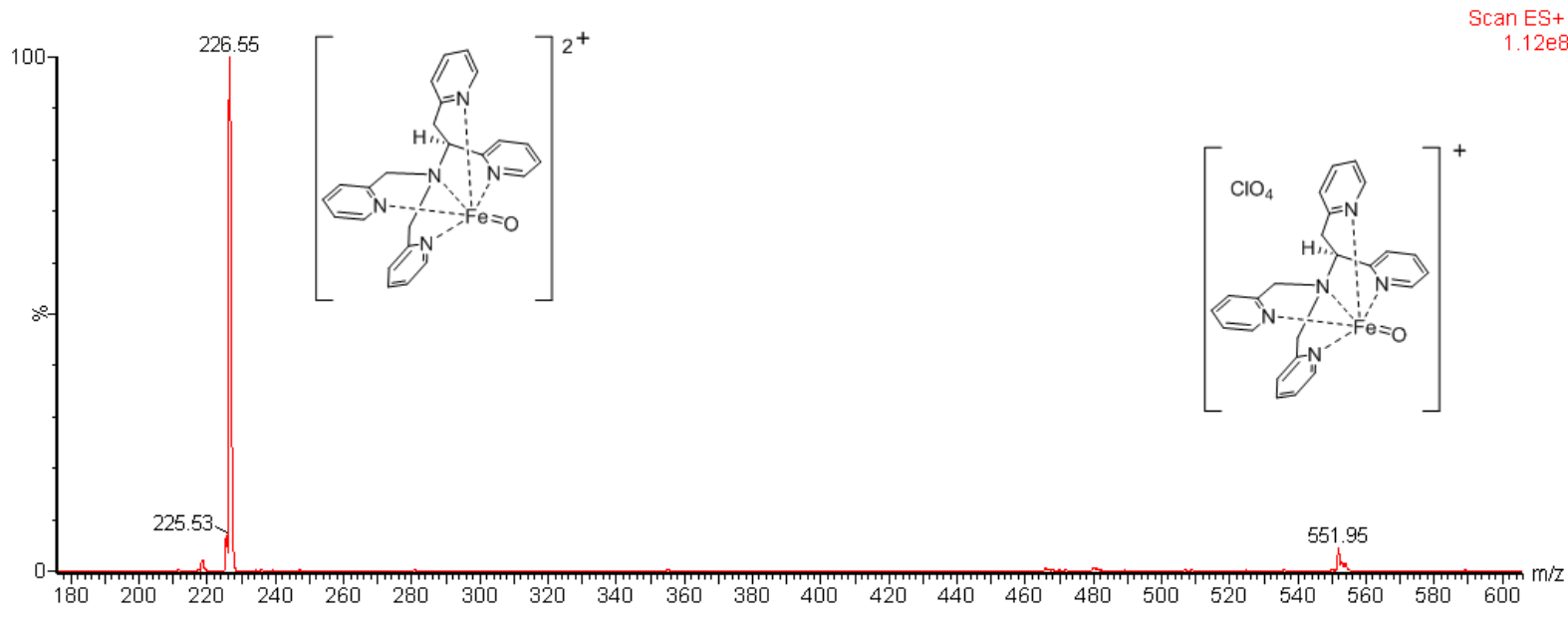

Figure S12. Electrospray ionization mass spectrum of $\mathbf{2}\left(\mathrm{ClO}_{4}\right)_{2}$. The peaks at $\mathrm{m} / \mathrm{z}$ values 226.55 and 551.95 correspond to the formulae $\left[\mathrm{Fe}^{\mathrm{IV}}(\mathrm{O})(\operatorname{asN} 4 \mathrm{Py})\right]^{2+}(\mathrm{z}=2)$ and $\left[\mathrm{Fe}^{\mathrm{IV}}(\mathrm{O})(\operatorname{asN} 4 \mathrm{Py})\left(\mathrm{ClO}_{4}\right)\right]^{+}(\mathrm{z}=1)$, respectively. 


\section{Measurements}

The spectrum of ((+)-(S)-asN4Py displays a negative feature at $277 \mathrm{~nm}$ and two positive peaks centered at 255 and $211 \mathrm{~nm}$. (+)-(S) 1 displays a broad positive maximum around 400 $\mathrm{nm}$ centered at the intense metal-to-ligand charge-transfer transition observed in the UVvisible spectrum. A negative doublet is also observed at 330 and $315 \mathrm{~nm}$. A negative maximum at $260 \mathrm{~nm}$ and two positive maxima at 240 and $220 \mathrm{~nm}$ are also observed probably corresponding to ligand-centered charge-transfer transitions. The Fe(IV)-oxo intermediates were prepared by adding PhIO to the initial Fe(II) solutions. The Fe(IV)-oxo complexes do not display significant CD features in the 400-900 nm range. The complex (+)- $(S) 2$ displays a positive maximum at $320 \mathrm{~nm}$ as well as ligand-centered features at 365 (negative) and $245 \mathrm{~nm}$ (positive).

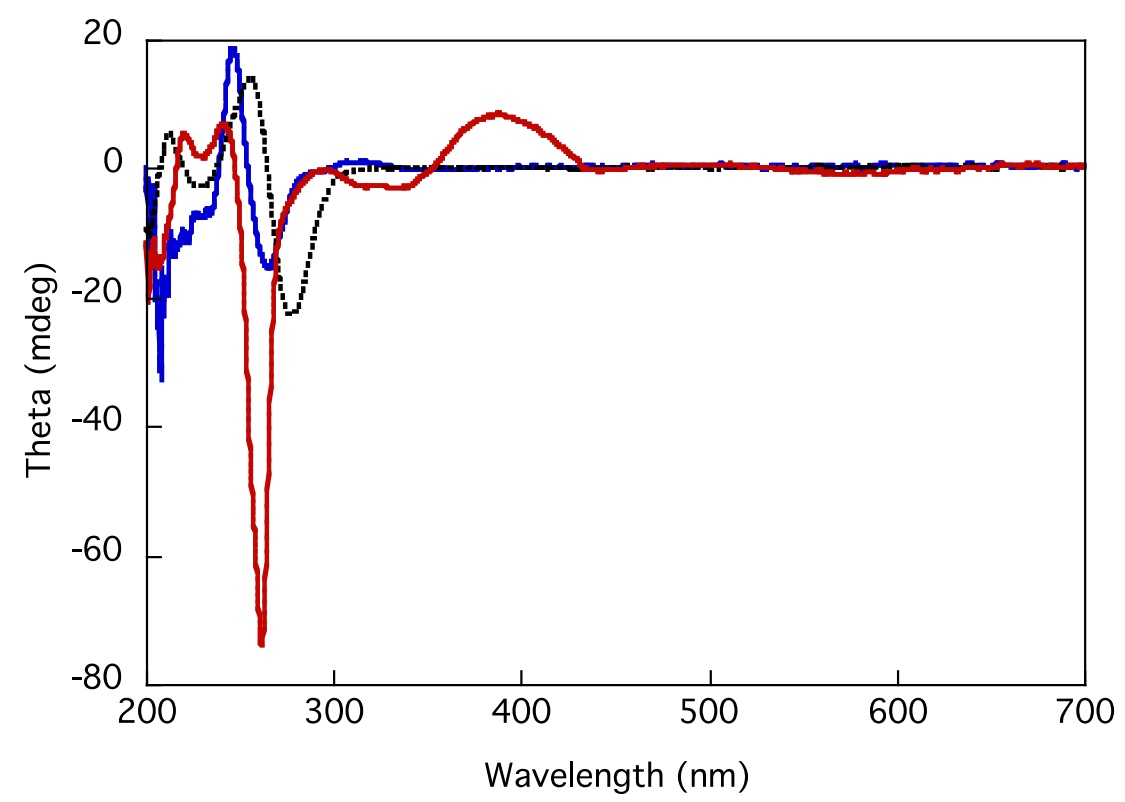

Figure S13. CD spectra of (+)-asN4Py (dotted black line), (+)-1 $\left(\mathrm{ClO}_{4}\right)_{2}$ (red line) and (+)$\mathbf{2}\left(\mathrm{ClO}_{4}\right)_{2}$ (blue line). Concentrations of $1 \mathrm{mM}$ in acetonitrile were used.

\section{Oxidation reactions}

\section{Description of the Fe(IV) intermediate formation with TBHP}

$\mathbf{1}\left(\mathrm{ClO}_{4}\right)_{2}$ complex $\left(2.00 \times 10^{-3} \mathrm{M}\right)$ was dissolved in acetonitrile $(1.5 \mathrm{~mL})$, TBHP $(\mathrm{CHP})(2.00$ $\left.\times 10^{-1} \mathrm{M}\right)$ was added to the solution and the reaction was monitored with UV-vis spectrophotometer (Agilent 8453) at $705 \mathrm{~nm}\left(\varepsilon=400 \mathrm{M}^{-1} \mathrm{~cm}^{-1}\right)$. 

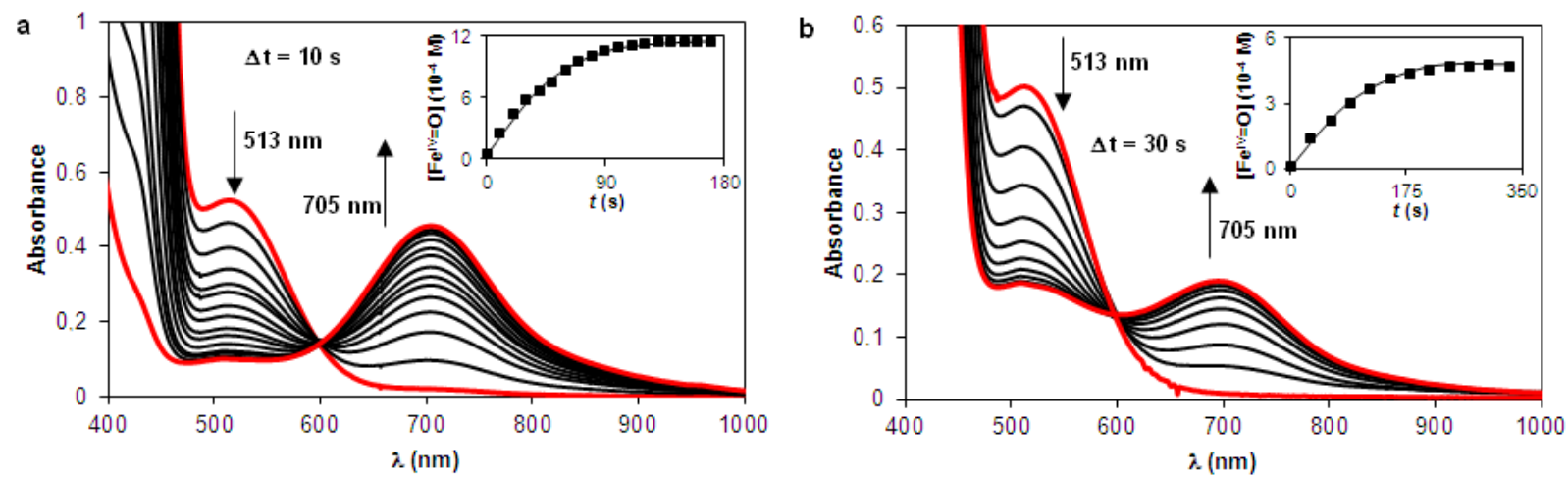

Figure S14. Visible spectral change for the formation of 2 species (at $705 \mathrm{~nm}$ ) derived from the reaction of 1 with TBHP (a) or CHP (b) in MeCN at $298 \mathrm{~K}$. Inset: Time dependent formation of 2 under the conditions described above. $\left[\mathbf{1}\left(\mathrm{ClO}_{4}\right)_{2}\right]_{0}=2.00 \times 10^{-3} \mathrm{M},[\mathrm{TBHP}]_{0}=$ $2.00 \times 10^{-2} \mathrm{M},[\mathrm{CHP}]_{0}=2.00 \times 10^{-2} \mathrm{M}$.

Table S5. Kinetic data for the reaction of $\mathbf{1}\left(\mathrm{ClO}_{4}\right)_{2}$ with TBHP in MeCN at different temperatures.

\begin{tabular}{c|c|c|c|c|c|c}
\hline $\mathrm{N}_{0}$ & $\mathrm{~T}(\mathrm{~K})$ & {$[\mathrm{Fe}]_{0}\left(10^{-3} \mathrm{M}\right)$} & {$[\mathrm{TBHP}]_{0}\left(10^{-1} \mathrm{M}\right)$} & $v\left(10^{-4} \mathrm{Ms}^{-1}\right)$ & $k_{\mathrm{obs}}\left(10^{-2} \mathrm{~s}^{-1}\right)$ & $k_{2}\left(10^{-1} \mathrm{M}^{-1} \mathrm{~s}^{-1}\right)$ \\
\hline 1 & 298 & 0.5 & 2 & 0.28 & 5.59 & 2.79 \\
2 & 298 & 1 & 2 & 0.49 & 4.96 & 2.48 \\
3 & 298 & 2 & 2 & 1.32 & 6.64 & 3.32 \\
4 & 298 & 5 & 2 & 2.79 & 5.59 & 2.79 \\
5 & 298 & 10 & 2 & 6.30 & 6.30 & 3.15 \\
6 & 298 & 2 & 0.2 & 0.15 & 0.74 & 3.72 \\
7 & 298 & 2 & 0.5 & 0.39 & 1.94 & 3.88 \\
8 & 298 & 2 & 1 & 0.57 & 2.85 & 2.85 \\
9 & 298 & 2 & 1.5 & 0.97 & 4.84 & 3.23 \\
10 & 293 & 2 & 2 & 0.78 & 3.91 & 1.95 \\
11 & 303 & 2 & 2 & 1.83 & 9.16 & 4.58 \\
12 & 308 & 2 & 2.47 & 12.4 & 6.18 \\
13 & 298 & 2 & $0.2 *$ & 0.03 & 0.15 & 0.74 \\
\hline
\end{tabular}

* The oxidant was CHP.

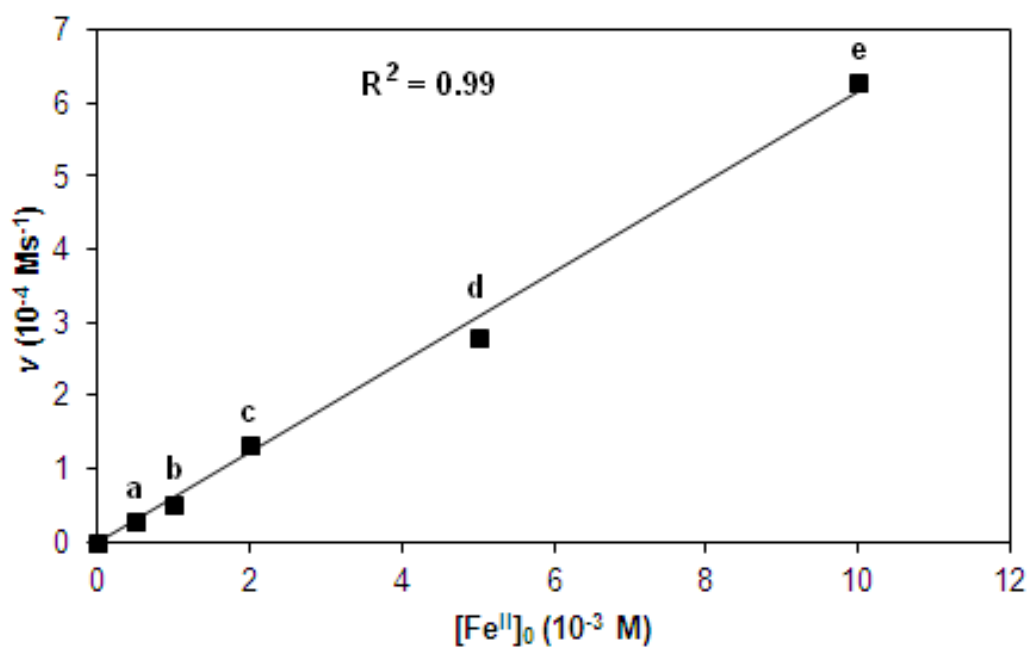

Figure S15. Reaction rates versus iron concentration in $\mathrm{MeCN}$ at $25^{\circ} \mathrm{C}$. $[\mathrm{TBHP}]_{0}=2.00 \times 10^{-}$ ${ }^{1} \mathrm{M},\left[\mathbf{1}\left(\mathrm{ClO}_{4}\right)_{2}\right]_{0}=5.00 \times 10^{-4} \mathrm{M}(\mathbf{a}) ; 1.00 \times 10^{-3} \mathrm{M}(\mathbf{b}) ; 2.00 \times 10^{-3} \mathrm{M}(\mathbf{c}) ; 5.00 \times 10^{-3} \mathrm{M}(\mathbf{d}) ;$ $1.00 \times 10^{-2} \mathrm{M}(\mathbf{e})$. 


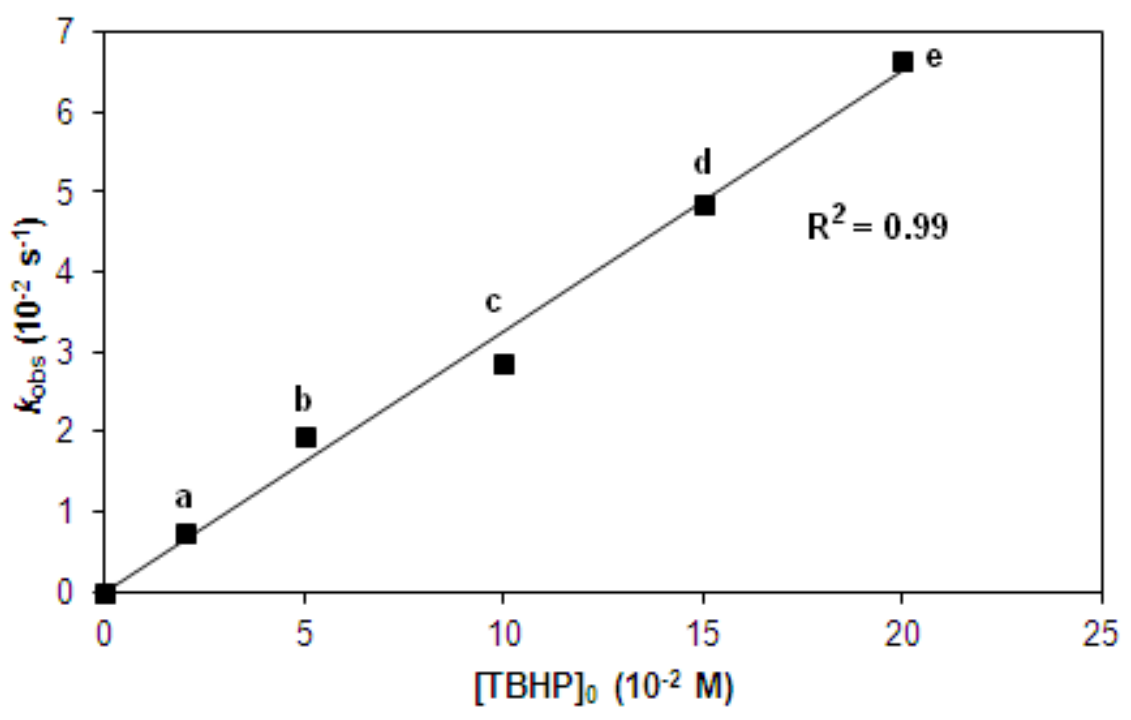

Figure S16. Reaction rates versus TBHP concentration in $\mathrm{MeCN}$ at $25{ }^{\circ} \mathrm{C}$.

$\left[\mathbf{1} \cdot\left(\mathrm{ClO}_{4}\right)_{2}\right]_{0}=2.00 \times 10^{-3} \mathrm{M},[\mathrm{TBHP}]_{0}=2.00 \times 10^{-2} \mathrm{M}(\mathbf{a}) ; 5.00 \times 10^{-2} \mathrm{M}(\mathbf{b}) ; 1.00 \times 10^{-1} \mathrm{M}$ (c); $1.50 \times 10^{-1} \mathrm{M}(\mathbf{d}) ; 2.00 \times 10^{-1} \mathrm{M}(\mathbf{e})$.

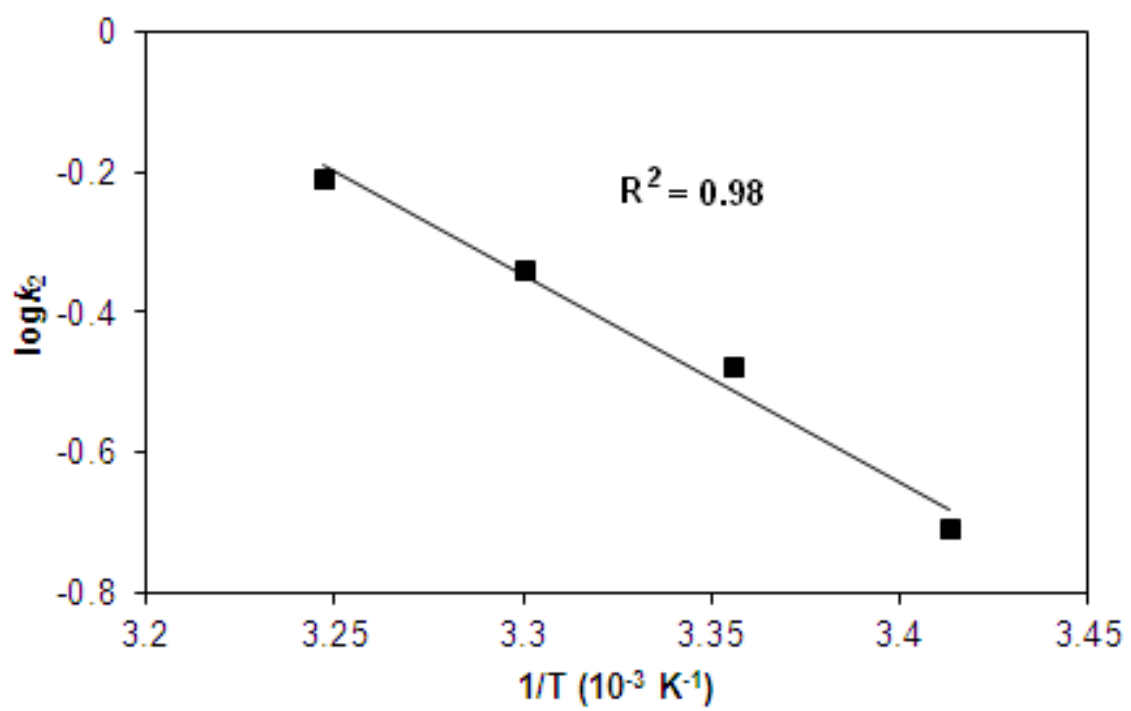

Figure S17. Arrhenius plot of the reaction of $\mathbf{1} \cdot\left(\mathrm{ClO}_{4}\right)_{2}$ with TBHP in MeCN. $\left[\mathbf{1}\left(\mathrm{ClO}_{4}\right)_{2}\right]_{0}=$ $2.00 \times 10^{-3} \mathrm{M},[\mathrm{TBHP}]_{0}=2.00 \times 10^{-1} \mathrm{M}$. 


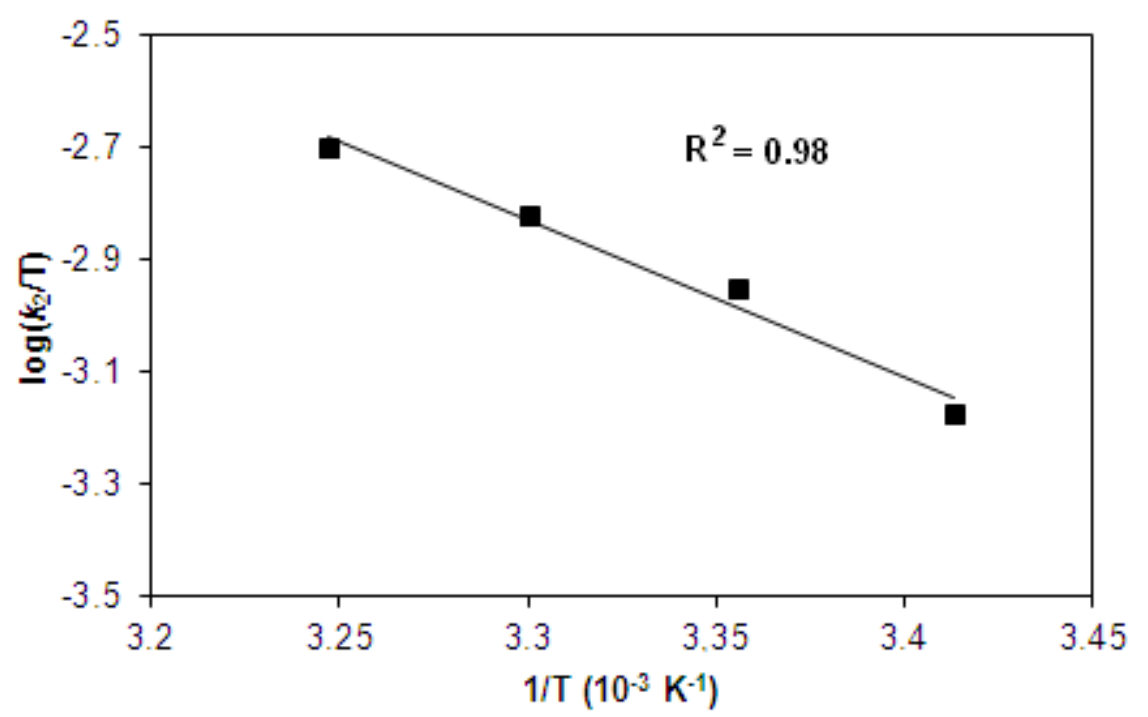

Figure S18. Eyring plot of the reaction of $\mathbf{1}\left(\mathrm{ClO}_{4}\right)_{2}$ with TBHP in MeCN. $\left[\mathbf{1}\left(\mathrm{ClO}_{4}\right)_{2}\right]_{0}=2.00 \times 10^{-3} \mathrm{M},[\mathrm{TBHP}]_{0}=2.00 \times 10^{-1} \mathrm{M}$.

Table S6. The calculated $E_{\mathrm{A}}, \Delta H^{\ddagger}$ and $\Delta S^{\ddagger}$ values in the reaction of $\mathbf{1}\left(\mathrm{ClO}_{4}\right)_{2}$ and TBHP in $\mathrm{MeCN}$.

\begin{tabular}{c|c|c}
\hline$E_{\mathrm{A}}\left(\mathrm{kJ} \mathrm{mol}^{-1}\right)$ & $\Delta H^{\ddagger}\left(\mathrm{kJ} \mathrm{mol}^{-1}\right)$ & $\begin{array}{c}\Delta S^{\ddagger}\left(\mathrm{J} \mathrm{mol}^{-1} \mathrm{~K}^{-1}\right) \\
\text { at } 25^{\circ} \mathrm{C}\end{array}$ \\
\hline 57 & 54 & -108 \\
\hline
\end{tabular}

\section{Description of the $\mathrm{Fe}(\mathrm{IV})$ intermediate formation with $\mathrm{PhIO}$}

$\mathbf{1}\left(\mathrm{ClO}_{4}\right)_{2}$ complex $\left(2.00 \times 10^{-3} \mathrm{M}\right)$ was dissolved in acetonitrile $(1.5 \mathrm{~mL})$, then iodosylbenzene $\left(4.00 \times 10^{-3} \mathrm{M}\right)$ was added to the solution. The mixture was stirred for 50 minutes then the excess iodosylbenzene was removed by filtration. Thioanisole $\left(2.00 \times 10^{-2}\right.$ M) was added to the solution and the reaction was monitored by UV-vis spectrophotometer (Agilent 8453) at $705 \mathrm{~nm}\left(\varepsilon=400 \mathrm{M}^{-1} \mathrm{~cm}^{-1}\right)$. 


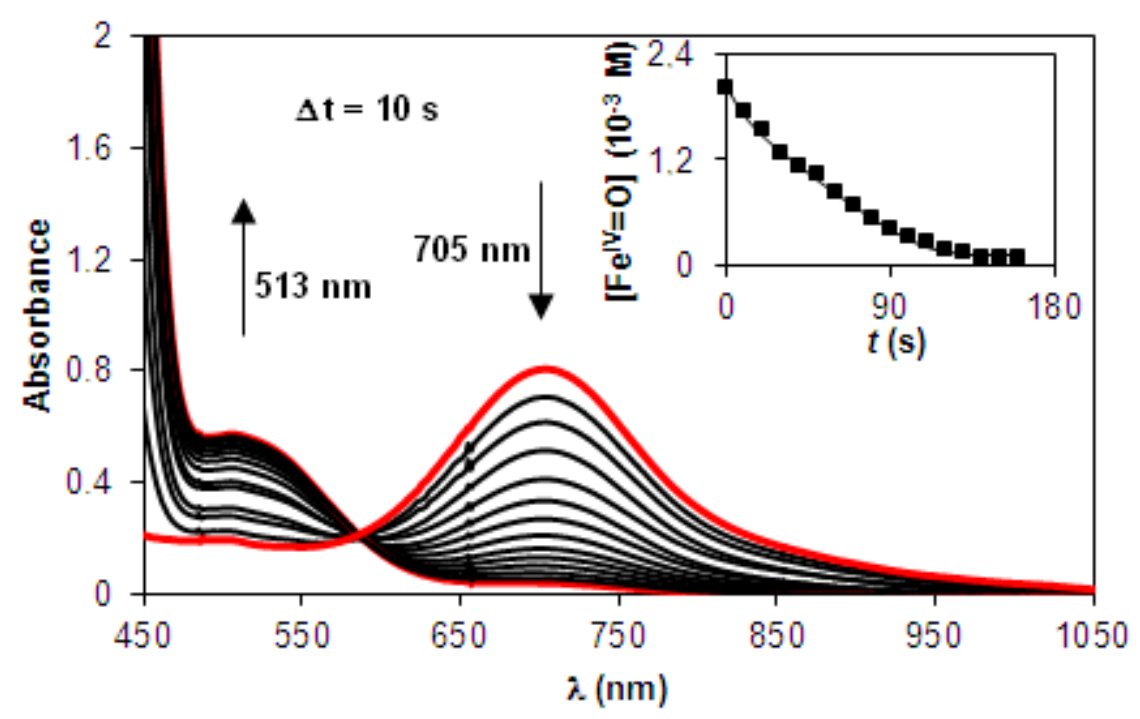

Figure S19. UV-vis spectral change of $\mathbf{2}\left(\mathrm{ClO}_{4}\right)_{2}$ upon addition of thioanisole at $298 \mathrm{~K}$. Inset shows time course of the decay of $\mathbf{2}\left(\mathrm{ClO}_{4}\right)_{2}$ monitored at $705 \mathrm{~nm}$.

$\left[2 \cdot\left(\mathrm{ClO}_{4}\right)_{2}\right]_{0}=2.00 \times 10^{-3} \mathrm{M}$, [thioanisole $]_{0}=4.00 \times 10^{-2} \mathrm{M}$.

Table S7. The calculated $v, k_{o b s}$ and $k_{2}$ values in the reaction of $\mathbf{2}\left(\mathrm{ClO}_{4}\right)_{2}$ and different thioanisole derivatives in $\mathrm{MeCN}$. $\left[2\left(\mathrm{ClO}_{4}\right)_{2}\right]_{0}=2.00 \times 10^{-3} \mathrm{M}$.

\begin{tabular}{c|c|c|c|c|c|c}
\hline $\mathrm{N}_{0}$ & $\mathrm{~T}(\mathrm{~K})$ & substrate & $\begin{array}{c}{[\text { substrate }]_{0}} \\
\left(10^{-1} \mathrm{M}\right)\end{array}$ & $\begin{array}{c}v \\
\left(10^{-5} \mathrm{Ms}^{-1}\right)\end{array}$ & $\begin{array}{c}k_{\text {obs }} \\
\left(10^{-2} \mathrm{~s}^{-1}\right)\end{array}$ & $\begin{array}{c}k_{2} \\
\left(10^{-1} \mathrm{M}^{-1} \mathrm{~s}^{-1}\right)\end{array}$ \\
\hline 1 & 298 & thioanisole & 0.2 & 1.15 & 0.58 & 2.88 \\
2 & 298 & thioanisole & 0.3 & 2.04 & 1.02 & 3.40 \\
3 & 298 & thioanisole & 0.4 & 2.46 & 1.23 & 3.07 \\
$4^{*}$ & 298 & thioanisole & 0.4 & 4.93 & 2.47 & 6.16 \\
5 & 298 & thioanisole & 0.6 & 3.22 & 1.61 & 2.68 \\
6 & 298 & thioanisole & 0.8 & 4.08 & 2.04 & 2.55 \\
7 & 298 & thioanisole & 1.0 & 5.48 & 2.74 & 2.73 \\
8 & 298 & thioanisole & 2.0 & 9.83 & 4.92 & 2.46 \\
9 & 298 & 4-methoxythioanisole & 0.2 & 2.72 & 1.36 & 6.80 \\
10 & 298 & methyl p-tolyl sulfide & 0.2 & 2.26 & 1.13 & 5.64 \\
11 & 298 & 4-chloro-thioanisole & 0.2 & 0.29 & 0.15 & 0.74 \\
12 & 298 & 4-nitro-thioanisole & 0.2 & 0.04 & 0.02 & 0.11 \\
13 & 293 & thioanisole & 0.2 & 0.94 & 0.47 & 2.34 \\
14 & 303 & thioanisole & 0.2 & 1.77 & 0.88 & 4.41 \\
15 & 308 & thioanisole & 0.2 & 2.26 & 1.13 & 5.65 \\
\hline
\end{tabular}

*The complex $\left[\mathrm{Fe}^{\mathrm{II}}\left(\mathrm{N}_{4} \mathrm{Py}\right)\left(\mathrm{CH}_{3} \mathrm{CN}\right)\right]\left(\mathrm{ClO}_{4}\right)_{2}$ was used in this case. 


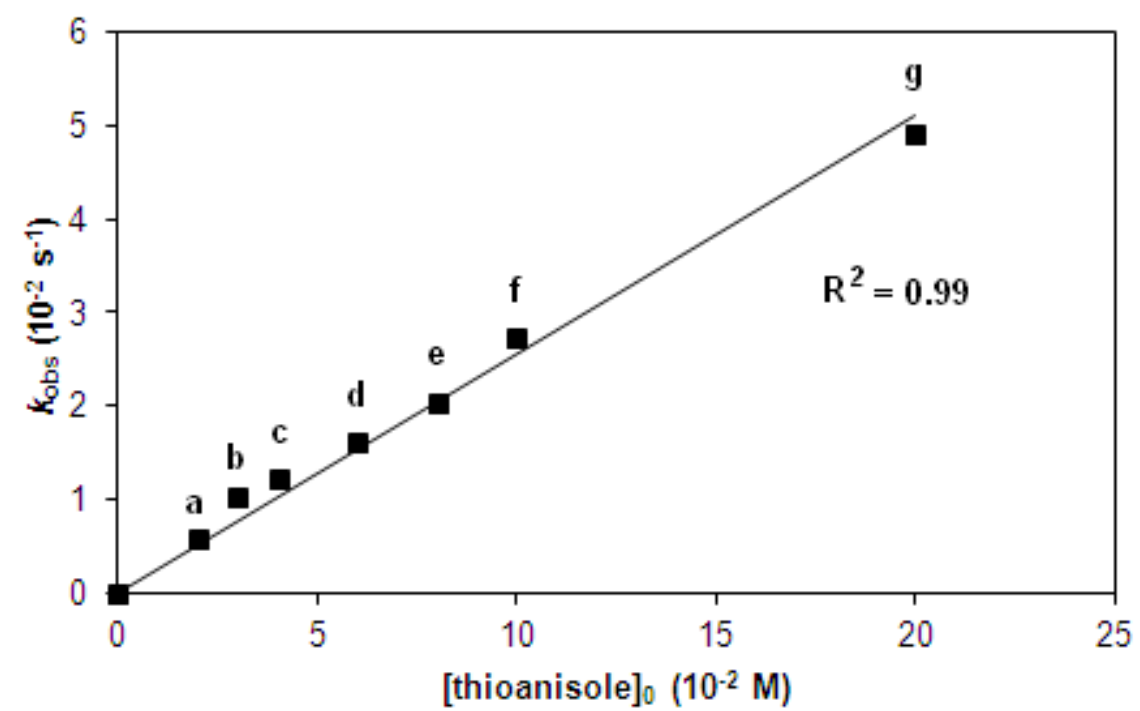

Figure S20. Reaction rates versus thioanisole concentration in $\mathrm{MeCN}$ at $25{ }^{\circ} \mathrm{C}$. $\left[\mathbf{2}\left(\mathrm{ClO}_{4}\right)_{2}\right]_{0}=$ $2.00 \times 10^{-3} \mathrm{M}$, [thioanisole $]_{0}=2.00 \times 10^{-2} \mathrm{M}(\mathbf{a}) ; 3.00 \times 10^{-2} \mathrm{M}(\mathbf{b}) ; 4.00 \times 10^{-2} \mathrm{M}(\mathbf{c}) ; 6.00 \times$ $10^{-2} \mathrm{M}(\mathbf{d}) ; 8.00 \times 10^{-2} \mathrm{M}(\mathbf{e}) ; 1.00 \times 10^{-1} \mathrm{M}(\mathbf{f}) ; 2.00 \times 10^{-1} \mathrm{M}(\mathbf{g})$.

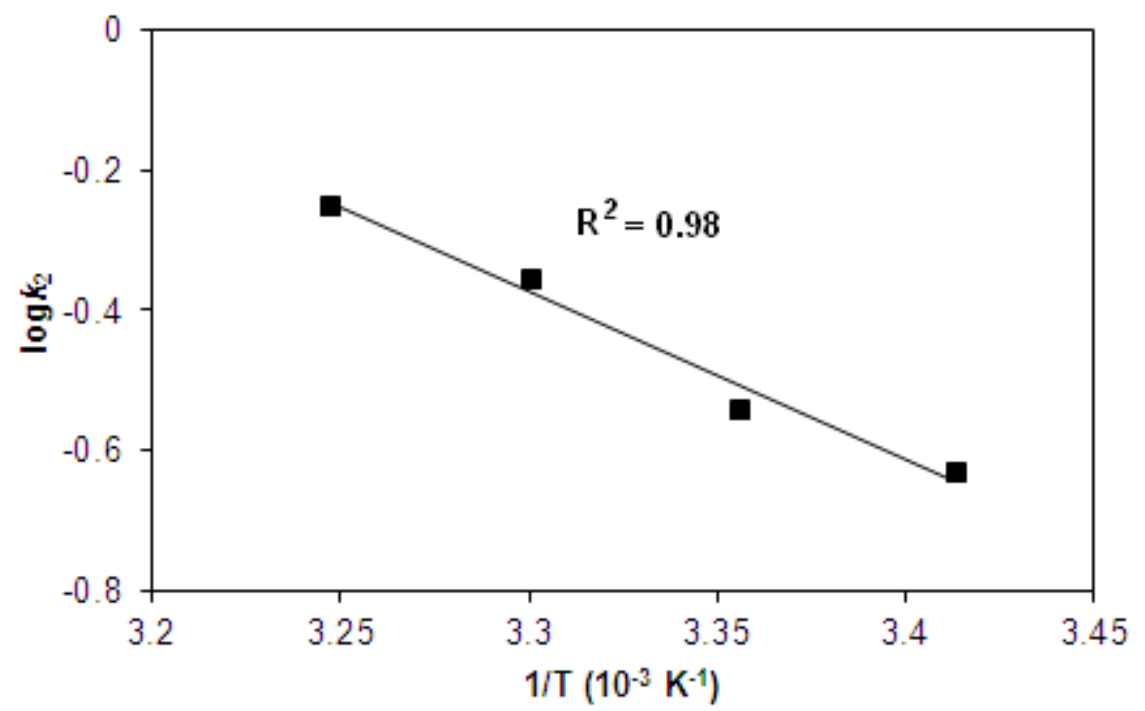

Figure S21. Arrhenius plot of $\mathbf{2} \cdot\left(\mathrm{ClO}_{4}\right)_{2}$ and thioanisole in $\mathrm{MeCN}$. $\left[\mathbf{2} \cdot\left(\mathrm{ClO}_{4}\right)_{2}\right]_{0}=2.00 \times 10^{-3}$ $\mathrm{M},[\text { thioanisole }]_{0}=2.00 \times 10^{-2} \mathrm{M}$. 


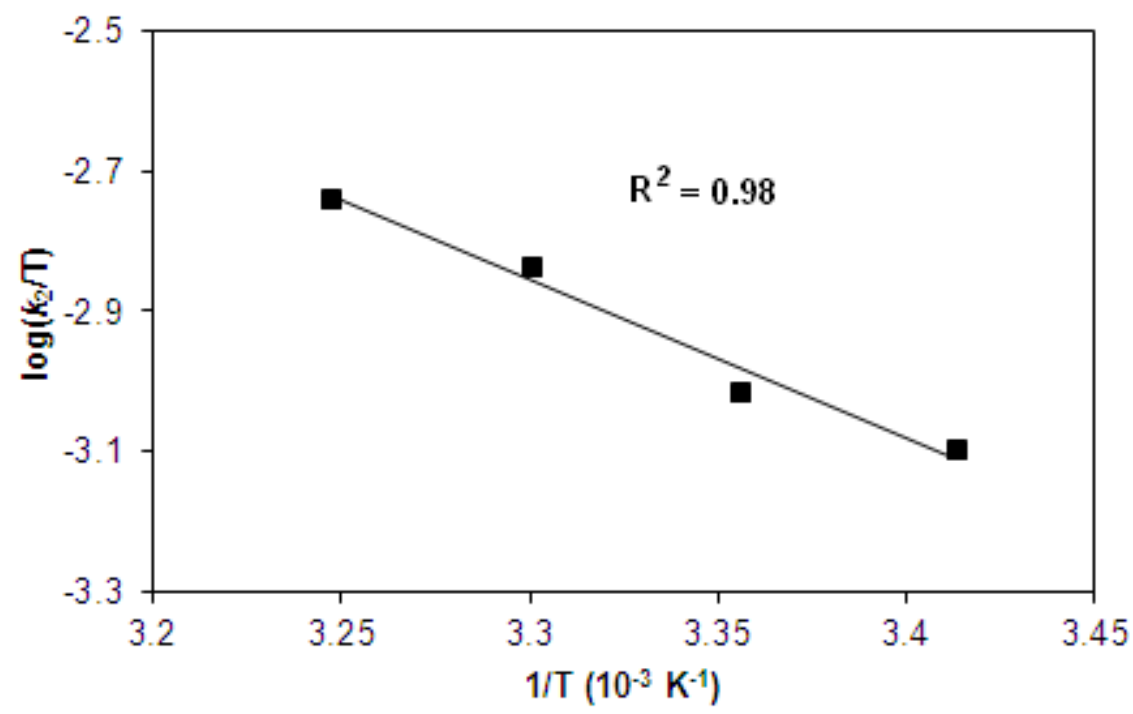

Figure S22. Eyring plot of $\mathbf{2}\left(\mathrm{ClO}_{4}\right)_{2}$ and thioanisole in $\mathrm{MeCN}$. $\left[2 \cdot\left(\mathrm{ClO}_{4}\right)_{2}\right]_{0}=2.00 \times 10^{-3} \mathrm{M}$, $\left[\right.$ thioanisole $_{0}=2.00 \times 10^{-2} \mathrm{M}$.

Table S8. The calculated $E_{\mathrm{A}}, \Delta H^{\ddagger}$ and $\Delta S^{\ddagger}$ values in the reaction of $\mathbf{2}\left(\mathrm{ClO}_{4}\right)_{2}$ and thioanisole in $\mathrm{MeCN}$.

\begin{tabular}{c|c|c}
\hline$E_{\mathrm{A}}\left(\mathrm{kJ} \mathrm{mol}^{-1}\right)$ & $\Delta H^{\ddagger}\left(\mathrm{kJ} \mathrm{mol}^{-1}\right)$ & $\Delta S^{\ddagger}\left(\mathrm{J} \mathrm{mol}^{-1} \mathrm{~K}^{-1}\right)$ at \\
& & $25^{\circ} \mathrm{C}$ \\
\hline 46 & 44 & -100 \\
\hline
\end{tabular}

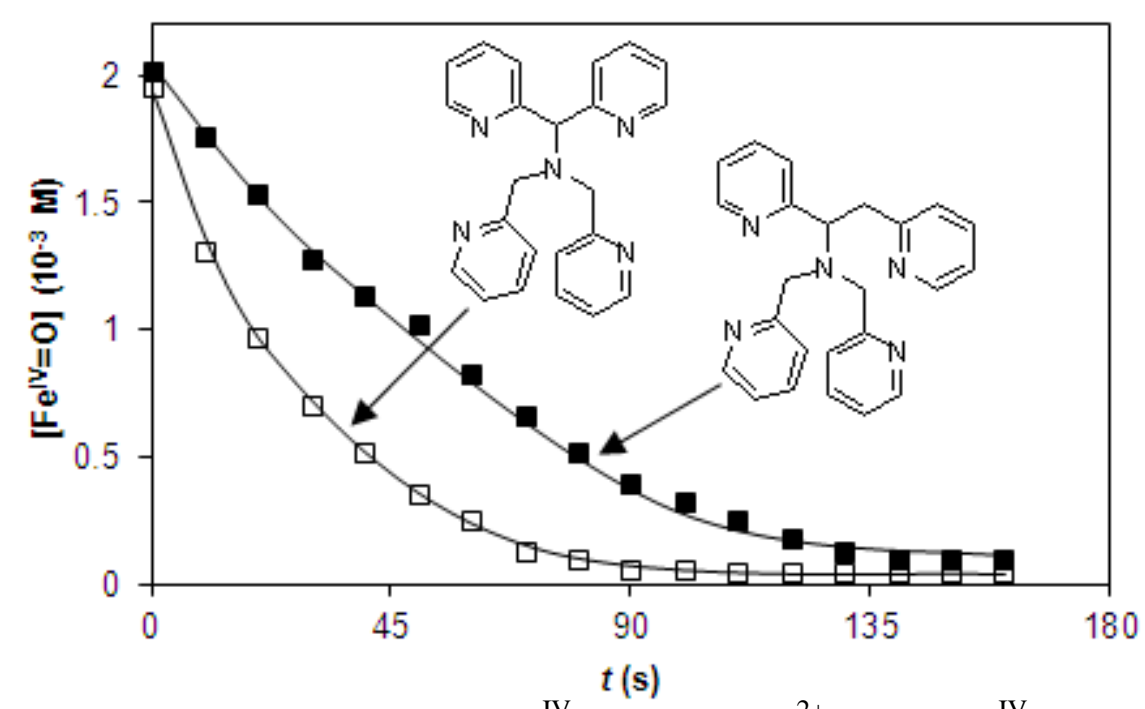

Figure S23. Time dependent decay of $\boldsymbol{\square}\left[\mathrm{Fe}^{\mathrm{IV}}=\mathrm{O}(\text { asN4Py })\right]^{2+}$ and $\square\left[\mathrm{Fe}^{\mathrm{IV}}=\mathrm{O}(\mathrm{N} 4 \mathrm{Py})\right]^{2+}$ in the reaction of $\left[\mathrm{Fe}^{\mathrm{IV}}(\mathrm{O})\left(\mathrm{asN}_{4} \mathrm{Py}\right)\right]\left(\mathrm{ClO}_{4}\right)_{2}$ or $\left[\mathrm{Fe}^{\mathrm{IV}}(\mathrm{O})\left(\mathrm{N}_{4} \mathrm{Py}\right)\right]\left(\mathrm{ClO}_{4}\right)_{2}$ with thioanisole in $\mathrm{MeCN}$ at $298 \mathrm{~K} .\left[2 \cdot\left(\mathrm{ClO}_{4}\right)_{2}\right]_{0}=2.00 \times 10^{-3} \mathrm{M},\left[\left[\mathrm{Fe}^{\mathrm{IV}}(\mathrm{O})\left(\mathrm{N}_{4} \mathrm{Py}\right)\right]\left(\mathrm{ClO}_{4}\right)_{2}\right]_{0}=2.00 \times 10^{-3} \mathrm{M}$, $[\text { thioanisole }]_{0}=4.00 \times 10^{-2} \mathrm{M}$. 

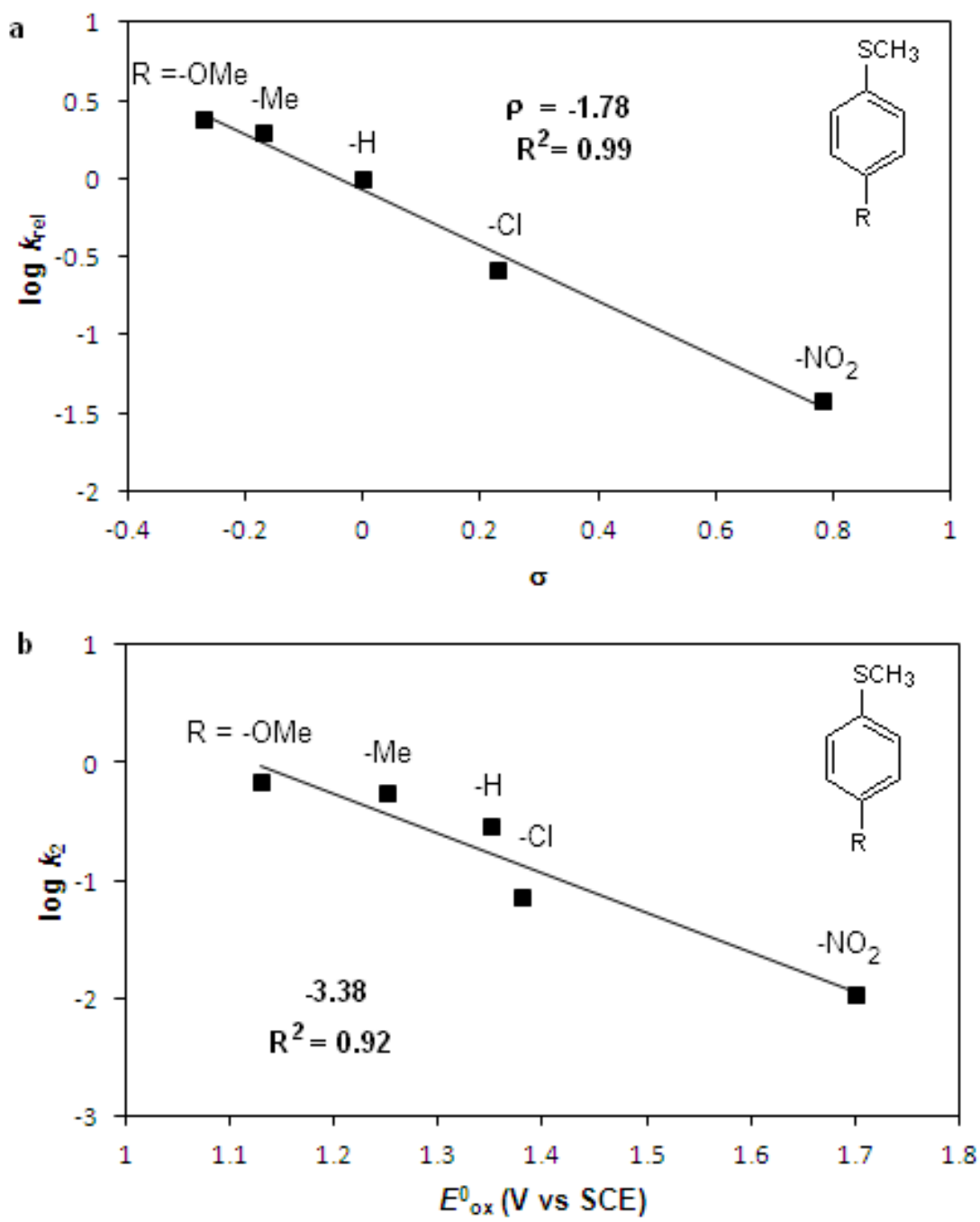

Figure S24. (a) Hammett plot for the oxidation of para-substituted thioanisoles in $\mathrm{MeCN}$ at 298 K. (b) Dependence of $\log k_{\text {obs }}$ on the $E^{0}{ }_{\text {ox }}$ of the para-substituted thioanisoles in MeCN at $25^{\circ} \mathrm{C}$. $[\text { substrate }]_{0}=2.00 \times 10^{-2} \mathrm{M},\left[2 \cdot\left(\mathrm{ClO}_{4}\right)_{2}\right]_{0}=2.00 \times 10^{-3} \mathrm{M}$

\section{Description of the asymmetric catalytic oxidation reaction}

$(S)-(+)-\mathbf{1}\left(\mathrm{ClO}_{4}\right)_{2}$ complex, $\left(6.45 \times 10^{-3} \mathrm{M}\right)$, 4-methoxythioanisole $\left(6.45 \times 10^{-1} \mathrm{M}\right)$ and iodosylbenzene or tert-butyl-hydroperoxide $\left(0.645 \times 10^{-1} \mathrm{M}\right)$ were dissolved in acetonitrile $(5$ $\mathrm{mL}$ ) then the mixture was stirred at $35^{\circ} \mathrm{C}$ for 5 minutes (with TBHP and $\mathrm{CHP}$ ), for 50 minutes (with PhIO). The products were identified by GC on a $\beta$-dex and $\gamma$-dex column described above. The yield of 4'- $\mathrm{MeOPhS}(\mathrm{O}) \mathrm{Me}$ and 4'- $\mathrm{MeOPhSO}_{2} \mathrm{Me}$ were calculated based on the amount of oxidant (CHP, TBHP, and PhIO) using bromobenzene as an internal standard in the reactions. Enantiomeric excess was determined with GC analysis on chiral columns ( $\beta$ $\operatorname{dex}, \gamma$-dex $):([R]-[S]) /([R]+[S])$. 


\section{Description of the asymmetric stoichiometric oxidation reaction}

$(S)-(+)-\mathbf{1}\left(\mathrm{ClO}_{4}\right)_{2}$ complex $\left(6.45 \times 10^{-3} \mathrm{M}\right)$ was dissolved in acetonitrile $(1.0 \mathrm{~mL})$, then iodosylbenzene $\left(1.29 \times 10^{-2} \mathrm{M}\right)$ was added to the solution. The mixture was stirred for 50 minutes then the excess iodosylbenzene was removed by filtration. 4-methoxythioanisole $\left(6.45 \times 10^{-1} \mathrm{M}\right)$ was added to the solution and the mixture was stirred at $35^{\circ} \mathrm{C}$ for 5 minutes. The products were identified by GC and the yield of 4'-MeOPhS(O)Me and 4'$\mathrm{MeOPhSO}_{2} \mathrm{Me}$ were calculated based on the amount of iron(IV)-oxo using bromobenzene as an internal standard in the reactions. Enantiomeric excess was determined with GC analysis on chiral columns $(\beta-\operatorname{dex}, \gamma$-dex $):([\mathrm{R}]-[\mathrm{S}]) /([\mathrm{R}]+[\mathrm{S}])$. 


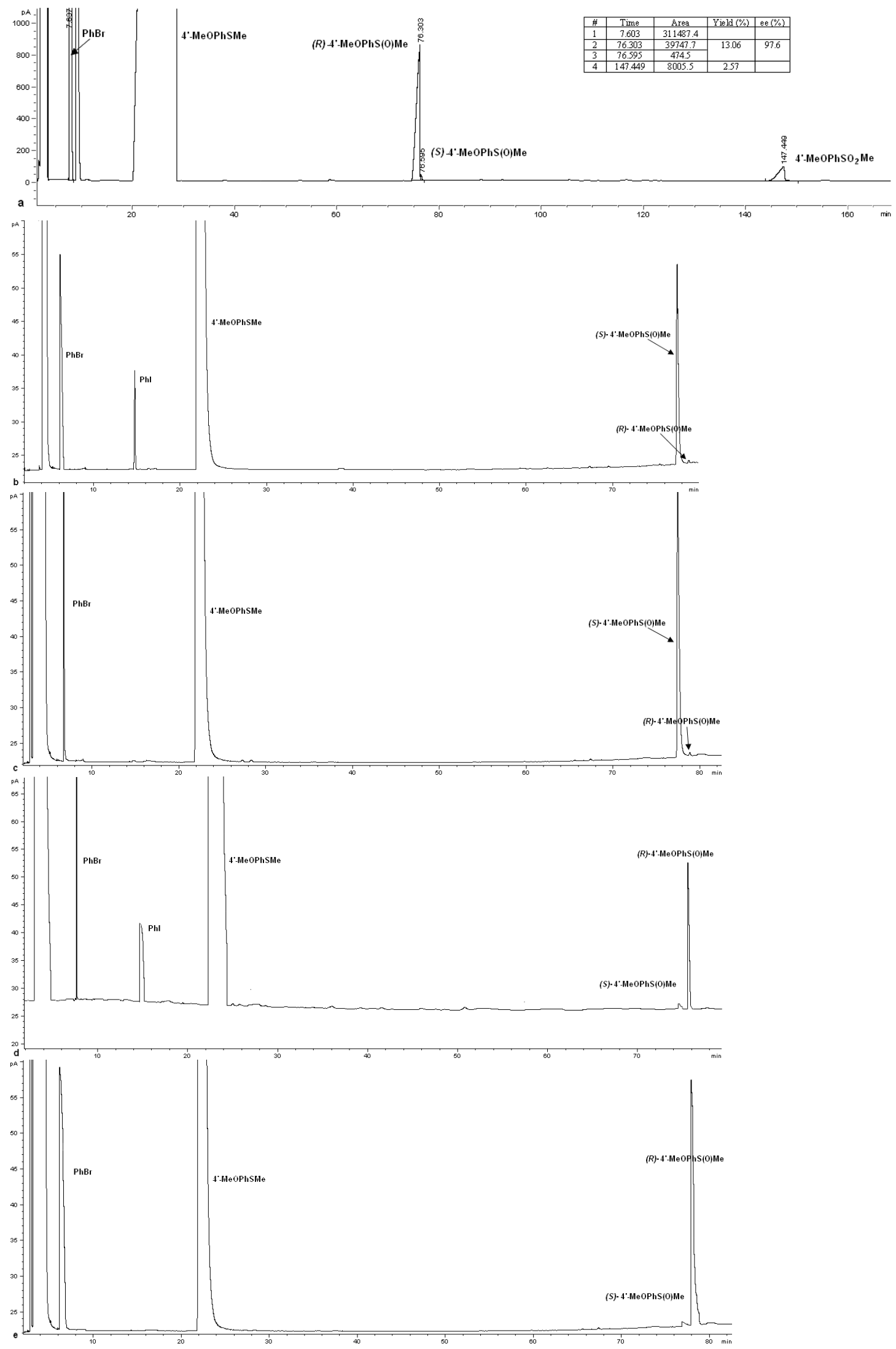

Figure S25. The GC chromatogram of the reaction of 4-methoxythioanisole, $\mathbf{1}\left(\mathrm{ClO}_{4}\right)_{2}$ and CHP (a) (with $\gamma$-dex chiral column); 4-methoxythioanisole, $(S)-(+)-\mathbf{1}\left(\mathrm{ClO}_{4}\right)_{2}$ and $\mathrm{PhIO}(\mathbf{b})$; 4methoxythioanisole, $(S)-(+)-\mathbf{1}\left(\mathrm{ClO}_{4}\right)_{2}$ and TBHP $(\mathbf{c})$; 4-methoxythioanisole, $(R)-(-)-\mathbf{1}\left(\mathrm{ClO}_{4}\right)_{2}$ and $\mathrm{PhIO}(\mathbf{d})$; 4-methoxythioanisole, $(R)-(-)-\mathbf{1}\left(\mathrm{ClO}_{4}\right)_{2}$ and TBHP $(\mathbf{e})$ in $\mathrm{MeCN}$ at $35^{\circ} \mathrm{C}$. $[(S)-$ 
$\left.(+)-\mathbf{1}\left(\mathrm{ClO}_{4}\right)_{2}\right]_{0}=6.45 \times 10^{-3} \mathrm{M},[\mathrm{CHP}, \mathrm{TBHP}, \mathrm{PhIO}]_{0}=6.45 \times 10^{-2} \mathrm{M},[4-$ methoxythioanisole $]_{0}=6.45 \times 10^{-1} \mathrm{M}$.
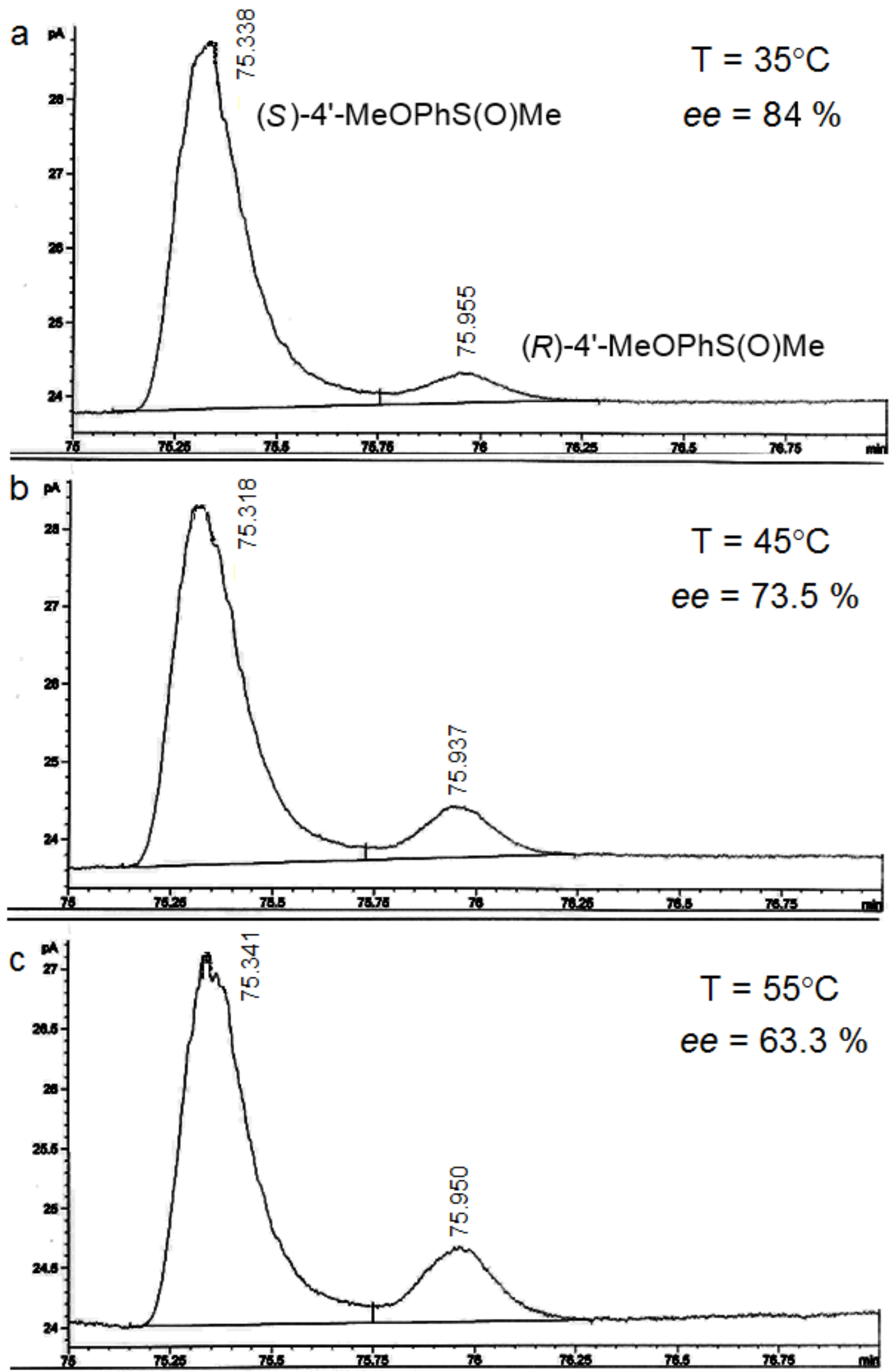

Figure S26. The GC chromatogram of the reaction of $(S)-(+)-2\left(\mathrm{ClO}_{4}\right)_{2}$ and 4methoxythioanisole in $\mathrm{MeCN}$ at $35^{\circ} \mathrm{C}(\mathbf{a}), 45^{\circ} \mathrm{C}(\mathbf{b})$ and $55^{\circ} \mathrm{C}(\mathbf{c}) \cdot\left[(S)-(+)-\mathbf{1}\left(\mathrm{ClO}_{4}\right)_{2}\right]_{0}=6.45$ $\times 10^{-3} \mathrm{M},[\mathrm{PhIO}]_{0}=1.29 \times 10^{-2} \mathrm{M},[4-\text { methoxythioanisole }]_{0}=6.45 \times 10^{-1} \mathrm{M}$. 

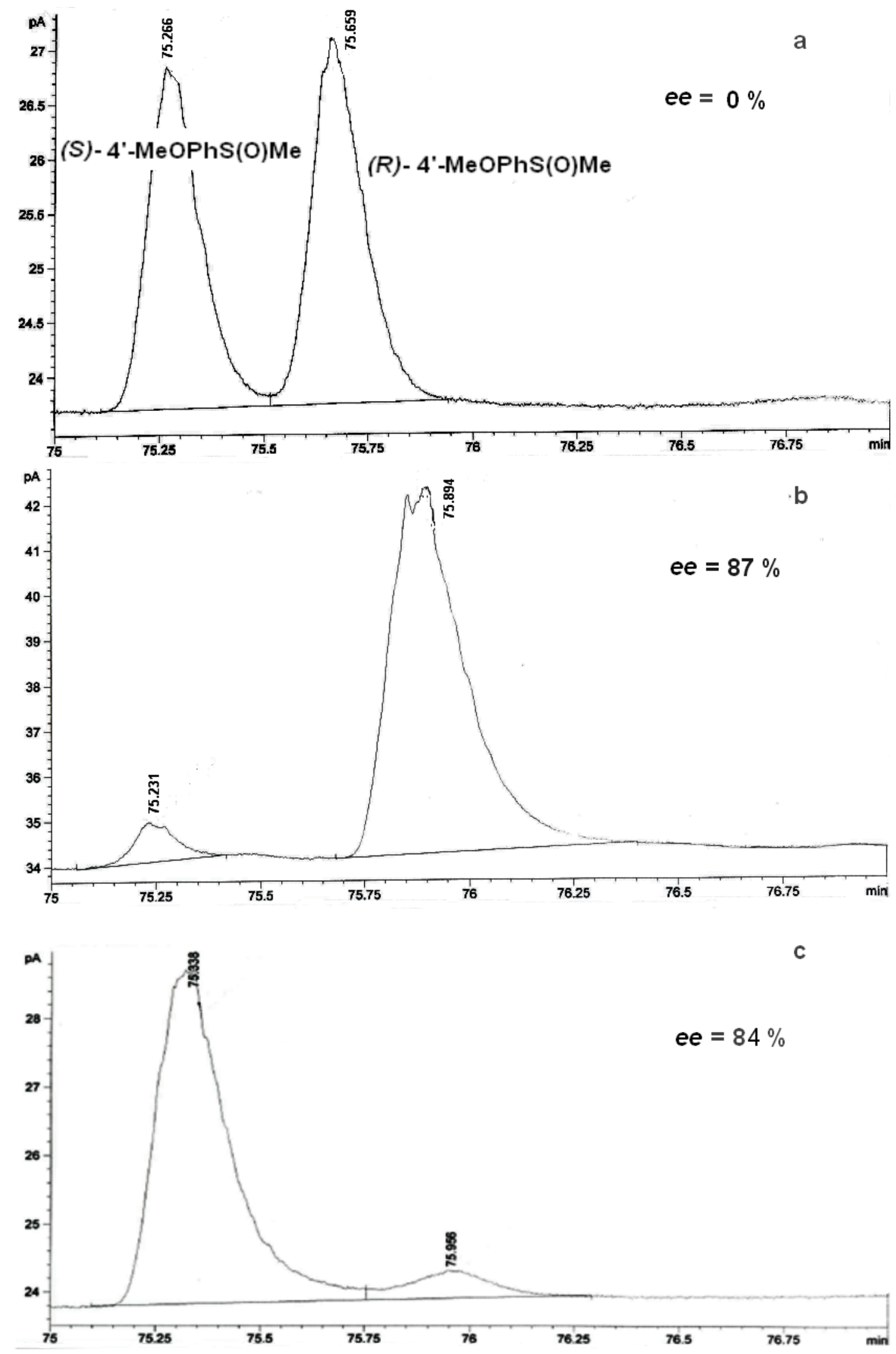

Figure S27. The GC chromatogram of the reaction of $\mathbf{2}\left(\mathrm{ClO}_{4}\right)_{2}(\mathbf{a}),(R)-(-)-\mathbf{2}\left(\mathrm{ClO}_{4}\right)_{2}(\mathbf{b}),(S)-$ $(+)-2 \cdot\left(\mathrm{ClO}_{4}\right)_{2}(\mathrm{c})$ and 4-methoxythioanisole in $\mathrm{MeCN}$ at $35^{\circ} \mathrm{C} .\left[2 \cdot\left(\mathrm{ClO}_{4}\right)_{2}\right]_{0}=6.45 \times 10^{-3} \mathrm{M}$, $[\mathrm{PhIO}]_{0}=1.29 \times 10^{-2} \mathrm{M},[4-\text {-methoxythioanisole }]_{0}=6.45 \times 10^{-1} \mathrm{M}$. 


\section{References}

(1) Sheldrick, G. M. Acta Crystallogr. 2008, A64, 112-122.

(2) Lázár, K.; Matusek, K.; Mink, J.; Dobos, S.; Guczi, L.; Vizi-Orosz, A.; Markó, L.; Reiff, W. M. J. Catal. 1984, 87, 163-178.

(3) Lubben, M.; Meetsma, A.; Wilkinson, E. C.; Feringa, B.; Que, L., Jr. Angew. Chem. Int. Ed. Engl. 1995, 34, 1512-1514.

(4) Negi, S.; Matsukura, M.; Mizuno, M.; Miyake, K.; Minami, N., Synthesis 1996, 991-996.

(5) AMPAC 10, 1992-2013 Semichem, Inc. 12456 W 62nd Terrace - Suite D, Shawnee, KS 66216.

(6) Gaussian 09, Revision D.01, Frisch MJ, Trucks GW, Schlegel HB, Scuseria GE, Robb MA, Cheeseman JR, Scalmani G, Barone V, Mennucci B, Petersson GA, Nakatsuji H, Caricato M, Li X, Hratchian HP, Izmaylov AF, Bloino J, Zheng G, Sonnenberg JL, Hada M, Ehara M, Toyota K, Fukuda R, Hasegawa J, Ishida M, Nakajima T, Honda Y, Kitao O, Nakai H, Vreven T, Montgomery JA, Peralta JE, Ogliaro F, Bearpark M, Heyd JJ, Brothers E, Kudin KN, Staroverov VN, Kobayashi R, Normand J, Raghavachari K, Rendell A, Burant JC, Iyengar SS, Tomasi J, Cossi M, Rega N, Millam JM, Klene M, Knox JE, Cross JB, Bakken V, Adamo C, Jaramillo J, Gomperts R, Stratmann RE, Yazyev O, Austin AJ, Cammi R, Pomelli C, Ochterski JW, Martin RL, Morokuma K, Zakrzewski VG, Voth GA, Salvador P, Dannenberg JJ, Dapprich S, Daniels AD, Farkas Ö, Foresman JB, Ortiz JV, Cioslowski J, Fox DJ. Gaussian Inc., 2013, Wallingford CT.

(7) Mitra, M.; Nimir, H.; Demeshko, S.; Bhat, S. S.; Malinkin, S. O.; Haukka, M.; LloretFillol, J.; Lisensky, G. C.; Meyer, F.; Shteinman, A. A.; Browne, W. R.; Hrovat, D. A.; Richmond, M. G.; Costas, M.; Nordlander, E. Inorg. Chem. 2015, 54, 7152-7164.

(8) Roelfes, G.; Lubben, M.; Chen, K.; Ho, R. Y. N.; Meetsma, A.; Genseberger, S.; Hermant, R. M.; Hage, R.; Mandal, S. K.; Young, V. G., Jr.; Zang, Y.; Kooijman, H.; Spek, A. L.; Que, L., Jr.; Feringa, B. L. Inorg. Chem. 1999, 38, 1929-1936.

(9) de Hoog, H. M.; Nallani, M.; Cornelissen, J. J. L. M.; Rowan, A. E.; Nolte, R. J. M.; Arends, I. W. C. E. Org. Biomol. Chem. 2009, 7, 4604-4610. 